Review

\title{
Technological options for the removal of arsenic with special reference to South East Asia
}

\author{
C.K. Jain ${ }^{\mathrm{a}, *}$, R.D. Singh ${ }^{\mathrm{b}}$

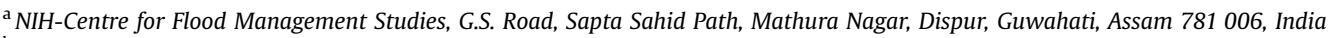 \\ ${ }^{\mathrm{b}}$ National Institute of Hydrology, Jal Vigyan Bhawan, Roorkee 247 667, India
}

\section{A R T I C L E I N F O}

\section{Article history:}

Received 26 September 2011

Received in revised form

22 March 2012

Accepted 9 April 2012

Available online 10 May 2012

\section{Keywords:}

Arsenic

Treatment technologies

Oxidation

Co-precipitation

Adsorption

Ion exchange

Membrane technology

\begin{abstract}
A B S T R A C T
Arsenic contamination in ground water, used for drinking purpose, has been envisaged as a problem of global concern. However, arsenic contamination of ground water in parts of South East Asia is assuming greater proportions and posing a serious threat to the health of millions of people. A variety of treatment technologies based on oxidation, co-precipitation, adsorption, ion exchange and membrane process are available for the removal of arsenic from ground water. However, question remains regarding the efficiency and applicability/appropriateness of the technologies, particularly because of low influent arsenic concentration and differences in source water composition. Some of these methods are quite simple, but the disadvantage associated with them is that they produce large amounts of toxic sludge, which needs further treatment before disposal into the environment. Besides, the system must be economically viable and socially acceptable. In this paper an attempt has been made to review and update the recent advances made in the technological development in arsenic removal technologies to explore the potential of those advances to address the problem of arsenic contamination in South East Asia.
\end{abstract}

(c) 2012 Elsevier Ltd. All rights reserved.

\section{Introduction}

Arsenic contamination in ground water, used for drinking purpose, has been envisaged as a problem of global concern. It has been reported from many parts of the world like Argentina, Australia, Bangladesh, Bolivia, Cambodia, Chile, China, Finland, Greece, Germany, Ghana, Hungary, India, Italy, Japan, Mexico, Mongolia, Myanmar, Nepal, Peru, Philippines, Romania, Spain, Taiwan, Thailand, USA and Vietnam (Robertson, 1986, 1989; Moncure et al., 1992; Schlottmann and Breit, 1992; Frost et al. 1993; Das et al., 1994, 1995; Chatterjee et al., 1995; Mandal et al., 1996; Ahmad et al., 1997; Berg et al., 2001; BGS, 2001; Tandukar et al., 2001; Alam et al., 2002; Mandal and Suzuki, 2002; Nordstrom, 2002; Smedley and Kinniburgh, 2002; Shrestha et al., 2003; Fytianos et al., 2004; Sun, 2004; Xia and Liu, 2004; Stranger et al., 2005; Mukherjee et al., 2006; Buschmann et al., 2007; Katsoyiannis and Katsoyiannis, 2006; Katsoyiannis et al., 2007). However, the natural arsenic contamination of ground water in parts of South and East Asia has assumed greater proportions and posing a serious threat to the health of millions

\footnotetext{
* Corresponding author. Tel.: +91 361 2331150; fax: +91 3612228823 .

E-mail address: ckj_1959@yahoo.co.in (C.K. Jain).
}

of people (Berg et al., 2001; WHO, 2001; Chakraborti et al., 2002; Mandal and Suzuki, 2002; Ng et al., 2003; Polya et al., 2005; Mukherjee et al., 2006). The countries affected in the region include Bangladesh (the worst affected), India, Myanmar, Nepal and Pakistan (South Asia); and Cambodia, China (including Taiwan), Lao People's Democratic Republic and Vietnam (East Asia). An estimated 60 million people are at risk from high levels of naturally-occurring arsenic in ground water, and at least 700,000 people in the region have thus far been affected by arsenicosis (World Bank, 2005a,b). Bangladesh has the highest percentage of contaminated shallow tube wells and an estimated 30 million people are dependent on those wells for domestic purposes (Heikens, 2006; Heikens et al., 2007). Most arsenic affected areas in South East Asia are reported from Bangladesh and West Bengal-India. Nine districts in West Bengal-India and 47 districts in Bangladesh have arsenic level in ground water above $50 \mu \mathrm{g} \mathrm{L}^{-1}$. The WHO guideline for arsenic in drinking water is $10 \mu \mathrm{g} \mathrm{L}^{-1}$. The area and population of the 47 districts in Bangladesh and 9 districts of West Bengal are $112407 \mathrm{~km}^{2}$ and 93.4 million, and $38.865 \mathrm{~km}^{2}$ and 42.7 million, respectively (Bhattacharya et al., 1997; Chowdhury et al., 1997; Chowdhury et al., 2000a,b; BGS and DPHE, 2001; Mukherjee and Bhattacharya, 2001; Rahman et al., 2001; Chakraborti et al., 2002, 2003, 2004; Singh, 2006). 
The high levels of arsenic in ground water in the affected countries are predominantly of geogenic origin. Reductive dissolution of iron (hydr)oxides $(\mathrm{FeOOH})$ stimulated by microbial activity and organic materials is regarded as the most important mechanism releasing arsenic into the aquifer (Nickson et al., 1998, 2000; Ravenscroft et al., 2001; Smedley and Kinniburgh, 2002; Smedley et al., 2003; Ahmed et al., 2004; McArthur et al., 2001, 2004; Zheng et al., 2004). Anthropogenic sources of arsenic include various industrial activities, pesticides, herbicides and fertilizers.

Over the past several years, numerous toxicological and epidemiological studies have been conducted to ascertain health risks associated with low-level exposure to arsenic ingestion. Ingestion of inorganic arsenic can result in both cancer and non-cancer health effects (NRC, 1999). Arsenic interferes with a number of essential physiological activities, including the actions of enzymes, essential cations and transcriptional events in cells (NRC, 1999). The US Environmental Protection Agency (USEPA) has classified arsenic as a Class ' $A$ ' human carcinogen. Chronic exposure to low arsenic levels has been linked to health complications, including cancer of the skin, kidney, lung and bladder, as well as other diseases of the skin, neurological and cardiovascular system (EPA, 2000a). The USEPA in 2001 adopted a new standard for arsenic in drinking water at $10 \mu \mathrm{g} \mathrm{L}^{-1}$ (EPA, 2001), replacing the old standard of $50 \mu \mathrm{g} \mathrm{L}^{-1}$.

Arsenic occur in the environment in different oxidation states and form various species, viz., $\operatorname{As}(\mathrm{V}), \operatorname{As}(\mathrm{III}), \operatorname{As}(0)$ and $\mathrm{As}(-\mathrm{III})$ (Braman and Foreback, 1973; Andreae, 1977; Shaikh and Tallman, 1978). The toxicity of different arsenic species varies in the order: arsenite $[\mathrm{As}(\mathrm{III})]>$ arsenate $[\mathrm{As}(\mathrm{V})]>$ monomethylarsonate (MMA) > dimethylarsinate (DMA) (Penrose, 1974; Lewis and Tatken, 1978; Stugeron et al., 1989). The valency state of arsenic plays an important role for the behavior of the element in the aqueous system. For example, toxicity of arsenic in trivalent state $[\mathrm{As}(\mathrm{III})]$ is higher than that of their pentavalent $[\mathrm{As}(\mathrm{V})]$ species (Berman, 1980; Gesamp, 1986). The valency state of an element also determines the sorption behavior and consequently the mobility in the aquatic environment. Jain and Ali (2000) have reported the occurrence, toxicity and speciation techniques for arsenic while Duker et al. (2005) described the toxic effects of arsenic as well as its mobilization in the natural environment.

In natural water, arsenic is mostly found in trivalent [As(III)] or pentavalent $[\mathrm{As}(\mathrm{V})]$ states. The distribution of arsenic species $[\mathrm{As}(\mathrm{III}), \mathrm{As}(\mathrm{V})]$ in natural waters is mainly dependent on redox potential and $\mathrm{pH}$ conditions (Cullen and Reimer, 1989). Under oxidizing conditions i.e., surface waters, the predominant species is pentavalent arsenic, which is mainly present in the oxyanionic forms $\left(\mathrm{H}_{2} \mathrm{AsO}_{4}^{-}, \mathrm{HAsO}_{4}^{2-}\right)$ with $\mathrm{pK}_{\mathrm{a} 1}=2.19, \mathrm{pK}_{\mathrm{a} 2}=6.94$ respectively. On the other hand, under mildly reducing conditions such as in anoxic ground waters, As(III) is the thermodynamically stable form, which at the $\mathrm{pH}$ values of most natural waters is present as nonionic arsenious acid $\left(\mathrm{H}_{3} \mathrm{AsO}_{3}, \mathrm{pK}_{\mathrm{a} 1}=9.22\right)$ (Cullen and Reimer, 1989). Similar findings were also reported by other researchers (Bose and Sharma, 2002; Kim et al., 2002; Ryu et al., 2002; Smedley and Kinniburgh, 2002). Recently, Katsoyiannis et al. (2007) explored arsenic speciation and concentrations to geological conditions and correlated with various redox indicative parameters and chemical components with their implications on ground water treatment. A significant correlation between $\mathrm{Eh}$ and arsenic speciation was observed with predominance of $\mathrm{As}(\mathrm{V})$ at higher Eh values (oxidizing conditions) and $\mathrm{As}(\mathrm{III})$ at lower Eh values (reducing conditions). A strong correlation was also observed between uranium concentrations and arsenic speciation, depicting their use as a possible indicator of ground water redox conditions (Katsoyiannis et al., 2007).
The removal of arsenic from water sources is generally accomplished by the application of conventional treatment methods such as oxidation, co-precipitation, adsorption, ion exchange and membrane process (Shen, 1973; Jekel, 1994; Hering and Elimelesh, 1995; Kartinen and Martin, 1995; Driehaus et al., 1998; Zouboulis and Katsoyiannis, 2002a,b). The specific methods adopted for the treatment of arsenic-contaminated water include flotation (Zhao et al., 1996), coagulation (Hering et al., 1997; Sancha, 2000), enhanced coagulation (Cheng et al., 1994), precipitation with sulfide (Bhattacharya et al., 1979), oxidation of As(III) followed by removal of total arsenic using ferric hydroxide, ferric chloride (Hering et al., 1996), iron-oxide coated sand (Joshi and Chaudhuri, 1996) and greensand filtration (Viraraghavan et al., 1996). A detailed review of arsenic removal technologies has been presented by Sorg and Logsdon (1974). Jekel (1994) has documented several advances in arsenic removal technologies. In view of the lowering the drinking water standards by USEPA, a review of arsenic removal technologies was made to consider the economic factors involved in implementing lower drinking water standards for arsenic (Chen et al., 1999). Many of the arsenic removal technologies have also been discussed in details in American Water Works Association reference book (Pontius, 1990). A comprehensive review of lowcost, well-water treatment technologies for arsenic removal has also been compiled by Murcott (2000).

During the last few years many small scale and community based arsenic removal technologies have been developed, fieldtested and used in various countries. However, question remains regarding the efficiency and applicability/appropriateness of the technologies, particularly because of low influent arsenic concentration and differences in source water composition. Some of these methods are quite simple, but the main disadvantage associated with them is that they produce large amounts of toxic sludge, which needs further treatment before disposal into the environment. Besides, the system must be economically viable and socially acceptable.

Speciation of arsenic and redox kinetics plays an important role in development and design of arsenic removal technologies. Therefore, a better understanding of arsenic speciation and redox kinetics is urgently needed for development of simple and reliable water treatment procedures. Most of the conventional methods for arsenic removal are not efficient in the removal of $\mathrm{As}(\mathrm{III})$ and therefore include a pre-oxidation step to achieve finished waters with total arsenic concentrations below $10 \mu \mathrm{g} \mathrm{L}^{-1}$ (Katsoyiannis et al., 2004, 2007). Keeping in view the above facts, an attempt has been made in this paper to review and update the recent advances made in the technological development in arsenic removal technologies to explore the potential of those advances in addressing the problem of arsenic contamination in ground water of South East Asia.

\section{Treatment technologies}

Various technologies available for removal of arsenic from contaminated water are based mainly on six principles:

i) Oxidation and filtration

ii) Biological oxidation: Oxidation of $\mathrm{As}(\mathrm{III})$ to $\mathrm{As}(\mathrm{V})$ by microorganisms and then removal of $\mathrm{As}(\mathrm{V})$ by iron and manganese oxides.

iii) Co-precipitation: Oxidation of $\mathrm{As}(\mathrm{III})$ to $\mathrm{As}(\mathrm{V})$ by adding suitable oxidizing agent followed by coagulation, sedimentation and filtration.

iv) Adsorption: Activated alumina, activated carbon, iron based sorbents, zero valent iron and hydrated iron oxide, etc. 
Enhanced Lime Softening

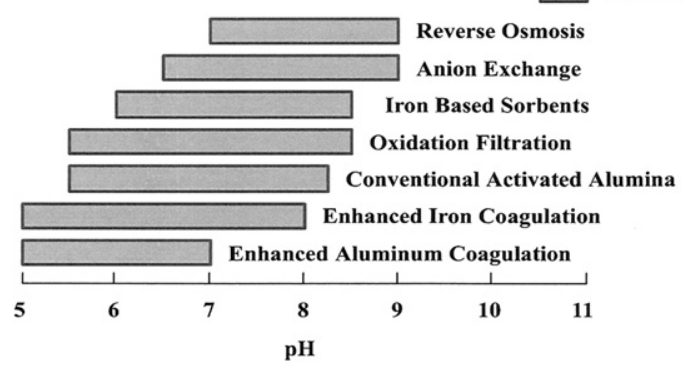

Fig. 1. Optimal pH Ranges for Arsenic Treatment Technologies.

v) Ion exchange through suitable cation and anion exchange resins.

vi) Membrane technology: Reverse osmosis, nanofiltration and electrodialysis.

Many of the arsenic treatment technologies require $\mathrm{pH}$ adjustment for optimization of performance and are effective in removing arsenic in pentavalent state and hence include an oxidation step as pre-treatment to convert $\mathrm{As}(\mathrm{III})$ to $\mathrm{As}(\mathrm{V})$ (Bissen and Frimmel, 2003). Fig. 1 gives a summary of the optimal $\mathrm{pH}$ ranges for several arsenic treatment technologies.

Sorption and coagulation processes are particularly sensitive to $\mathrm{pH}$ and function most effectively at the lower end of the natural $\mathrm{pH}$ range. However, use of AA at a natural $\mathrm{pH}$ may be a cost-effective option for many small water systems. In addition to affecting arsenic treatability, $\mathrm{pH}$ can also have a significant effect on disinfection, coagulation and chemical solubility/precipitation within distribution system (EPA, 2003a).

\subsection{Pre-treatment}

Chemicals such as chlorine, bleaching powder, ozone, hydrogen peroxide or potassium permanganate rapidly oxidize As(III) to $\mathrm{As}(\mathrm{V})$ under a wide range of conditions (Jekel, 1994; Molnar et al., 1994; Kim and Nriagu, 2000). Table 1 gives a summary of the benefits and drawbacks associated with the use of various oxidation technologies.

However, the use of chemical reagents in drinking water treatment is not recommended and should be avoided, because it often leads to undesirable by-products such as trihalomethanes (THMs), aldehydes, ketones, carboxylic acids and peroxides (Bull and
Kopfler, 1991; Gallard and Gunten, 2002). Ultraviolet (UV) light, by itself, is also ineffective. However, if the water is spiked with sulfite, UV photooxidation shows promise for As(III) conversion (Ghurye and Clifford, 2001).

Atmospheric oxygen is the most readily available oxidizing agent and many treatment processes prefer oxidation by air. But air oxidation of arsenic is a very slow process and it can take weeks for oxidation to occur (Pierce and Moore, 1982). Therefore, the reaction of As(III) oxidation need to be catalyzed to proceed on a time scale of few minutes. Edwards (1994) has reported that air oxidation of As(III) can be catalyzed by bacteria, strong acidic or alkali solutions, copper, powdered activated carbon and high temperature. However, oxidation kinetics of As(III) with natural and technical oxidants is not well understood. Kim and Nriagu (2000) studied oxidation of $\mathrm{As}(\mathrm{III})$ in ground water using ozone and oxygen and emphasized that although air oxidizes arsenic very slowly but when iron is present, the reaction goes very fast. This is because $\mathrm{Fe}(\mathrm{II})$ and $\mathrm{O}_{2}$ at $\mathrm{pH}$, produce $\mathrm{H}_{2} \mathrm{O}_{2}$ and in the presence of $\mathrm{Fe}(\mathrm{II})$ it oxidizes arsenic rapidly. Hug and Leupin (2003) studied ironcatalyzed oxidation of arsenic(III) by oxygen and by hydrogen peroxide and reported that As(III) was completely oxidized in the presence of $\mathrm{Fe}(\mathrm{II})$. Voegelin and Hug (2003) also studied the oxidation of $\mathrm{As}(\mathrm{III})$ by $\mathrm{H}_{2} \mathrm{O}_{2}$ in the presence of ferrihydrite and found that this reaction can be catalyzed on the surface of ferrihydrite, even though no oxidation was observed within minutes to hours prior to $\mathrm{H}_{2} \mathrm{O}_{2}$ addition. Hydrogen peroxide is a strong oxidizing agent and can contribute to the oxidation of $\mathrm{As}(\mathrm{III})$. Pettine et al. (1999) studied $\mathrm{As}(\mathrm{III})$ oxidation by $\mathrm{H}_{2} \mathrm{O}_{2}$ in aqueous solutions and reported that hydrogen peroxide does not oxidize arsenic if no iron is present in the water. It was further stated that oxidation of arsenic takes place only in the presence of iron or other divalent ions, which exert a catalytic effect on the oxidation of As(III). Dodd et al. (2006) also studied kinetics and mechanistic aspects of As(III) oxidation by aqueous chlorine, chloramines and ozone and its relevance to drinking water treatment.

As an alternative to chemical oxidation, several species of bacteria have also been found to mediate and catalyze arsenic oxidation process (Cullen and Reimer, 1989; Santini et al., 2000; Battaglia-Brunet et al., 2002) and has been successfully applied directly in continuous ground water treatment (Seith and Jekel, 1997; Katsoyiannis et al., 2002, 2004, 2008a,b; Katsoyiannis and Zouboulis, 2004a,b, 2006; Zouboulis and Katsoyoannis, 2002c). The process is based upon the fact that ground waters contaminated with arsenic are usually reducing and containing concentrations of iron and manganese. As(III) can be oxidized to $\mathrm{As}(\mathrm{V})$ by dissolved oxygen and this reaction is mediated by iron and

Table 1

Comparison of Oxidizing Agents.

\begin{tabular}{|c|c|c|}
\hline Oxidant & Benefits & Drawbacks \\
\hline Chlorine & $\begin{array}{l}\text { - Low relative cost } \\
\text { - Primary disinfection capability } \\
\text { - Secondary disinfectant residual } \\
\text { - } \mathrm{MnO}_{2} \text { media regenerant } \\
\text { - Oxidizes arsenic in less than } 1 \mathrm{~min}\end{array}$ & $\begin{array}{l}\text { - Formation of disinfection by-products } \\
\text { - Membrane fouling } \\
\text { - Special handling and storage requirements }\end{array}$ \\
\hline Permanganate & $\begin{array}{l}\text { - Unreactive with membranes } \\
\text { - No formation of disinfection by-products } \\
\text { - } \mathrm{MnO}_{2} \text { media regenerant? } \\
\text { - Oxidizes arsenic in less than } 1 \mathrm{~min}\end{array}$ & $\begin{array}{l}\text { - High relative cost } \\
\text {-No primary disinfection capability } \\
\text { - Formation of } \mathrm{MnO}_{2} \text { particulates } \\
\text { - Pink Water } \\
\text { - Difficult to handle } \\
\text { - An additional oxidant may be required for secondary disinfection }\end{array}$ \\
\hline Ozone & $\begin{array}{l}\text { - No chemical storage or handling required } \\
\text { - Primary disinfection capability } \\
\text { - No chemical by-products left in water } \\
\text { - Oxidizes arsenic in less than } 1 \text { min in the } \\
\text { absence of interfering reductants }\end{array}$ & $\begin{array}{l}\text { - Sulfide and TOC interfere with conversion and increase the } \\
\text { required contact time and ozone dose for oxidation } \\
\text { - An additional oxidant may be required for secondary disinfection }\end{array}$ \\
\hline
\end{tabular}


manganese-oxidizing bacteria which are indigenously present in ground water.

\subsection{Oxidation and filtration}

Oxidation and filtration normally refers to processes that are designed to remove naturally occurring iron and manganese from water. The processes involve the oxidation of the soluble forms of iron and manganese to their insoluble forms and then removal by filtration. If arsenic is present in the water, it can be removed via two primary mechanisms: adsorption and co-precipitation. First, soluble iron and $\mathrm{As}(\mathrm{III})$ are oxidized. The $\mathrm{As}(\mathrm{V})$ then adsorbs onto the iron hydroxide precipitates that are ultimately filtered out of solution. The arsenic removal efficiency is strongly dependent on the initial iron concentration and the ratio of iron to arsenic. In general, the Fe:As mass ratio should be at least 20:1. These conditions customarily result in an arsenic removal efficiency of 80-95\%. In some cases, it may be appropriate to add ferric coagulant in the beginning of the iron removal process to optimize arsenic removal. The effectiveness of arsenic co-precipitation with iron is relatively independent of source water $\mathrm{pH}$ in the range 5.5-8.5. However, high levels of organic mater, orthophosphates and silicates weaken arsenic removal efficiency by competing for sorption sites on iron hydroxide precipitates (Fields et al., 2000a,b).

Numerous authors have also described removal of arsenic by chemical oxidation and sorption onto manganese oxides (Edwards, 1994; Driehaus et al., 1995; Bajpai and Chaudhuri, 1999; Oscarson et al., 1983; Moore et al., 1990; Scott and Morgan, 1995; Nesbitt et al., 1998; Manning et al., 2002a,b; Tournassat et al., 2002). Since, manganese dioxides are capable of oxidizing As(III), it has been successfully used for removal of arsenic by chemical oxidation and sorption onto manganese oxides. Driehaus et al. (1995) studied oxidation of As(III) with manganese oxide and reported a second order rate law with respect to As(III). Oscarson et al. (1983) found a first order reaction rate in the redox reaction of various $\mathrm{MnO}_{2}$ modifications with $\mathrm{As}(\mathrm{III})$. The use of $\delta-\mathrm{MnO}_{2}$, which resembles the naturally occurring mineral birnessite, leads to a faster oxidation of As(III), compared to the $\alpha$ - and $\beta$-modification of $\mathrm{MnO}_{2}$. This can be explained by the low crystallinity and layered structure of the $\delta$ modification, which has easily available reaction sites with $\mathrm{Mn}^{4+}$ and $\mathrm{Mn}^{3+}$ in the interlayer of the solid. Moore et al. (1990) investigated the influence of $\mathrm{pH}$ and temperature on the oxidation of As(III) by $\delta-\mathrm{MnO}_{2}$ and suggested a structural based reaction scheme.

\subsubsection{Solar oxidation}

Hug et al. (2001) studied solar oxidation to remove arsenic from drinking water in Bangladesh with the objective to understand photo-induced $\mathrm{As}(\mathrm{III}, \mathrm{V})$ redox reactions and to develop a simple solar arsenic removal procedure that works at circumneutral $\mathrm{pH}$ with locally available materials, without $\mathrm{pH}$ adjustment and addition of chemicals. Poly(ethyleneterephthalate) (PET) bottles were used to expose drinking water to sunlight for solar disinfection. A strongly $\mathrm{Fe}(\mathrm{III})$ complexing ligand, citrate, has been used to improve photoproduction of $\mathrm{Fe}(\mathrm{II})$ at circumneutral $\mathrm{pH}$ (Hug et al., 1997). Reported quantum yields for the $\mathrm{Fe}(\mathrm{II})$ formation from photolysis of Fe(III) citrate are $0.21-0.28$ at $\mathrm{pH} 4-6$ with $436 \mathrm{~nm}$ light (Faust and Zepp, 1993) and $0.2-0.4$ at pH 5-7 at $366 \mathrm{~nm}$ (Abrahamson et al., 1994). In solutions containing $0.06-5 \mathrm{mg} \mathrm{L}^{-1}$ $\mathrm{Fe}(\mathrm{II},-\mathrm{III})$, over $90 \%$ of $\mathrm{As}(\mathrm{III})$ could be oxidized photochemically within $2-3$ h by illumination with $90 \mathrm{~W} / \mathrm{m}^{2} \mathrm{UV}-\mathrm{A}$ light. Citrate, by forming $\mathrm{Fe}(\mathrm{III})$ citrate complexes that are photolyzed with high quantum yields, strongly accelerated As(III) oxidation. The photoproduct of citrate (3-oxoglutaric acid) induced rapid flocculation and precipitation of $\mathrm{Fe}(\mathrm{III})$. In laboratory tests, $80-90 \%$ of total arsenic was removed after addition of $50 \mu \mathrm{M}$ citrate or $100-200 \mu \mathrm{L}$ (4-8 drops) of lemon juice/L, illumination for $2-3 \mathrm{~h}$, and precipitation. The same procedure was able to remove $45-78 \%$ of total arsenic in first field trials in Bangladesh. Citrate is readily available in most countries in the form of lemon or lime juice, which contains between 5 and 10\% of citric acid. Thus, addition of a few drops of lemon juice per liter of water can improve photooxidation of As(III) at circumneutral pH. The Department of Sanitary Engineering of All India Institute of Hygiene and Public Health (AIIH\&PH), West Bengal (India) has also studied the efficacy of arsenic removal by solar oxidation and precipitation and achieved 85-95\% arsenic removal. The method is applicable if the iron content in the ground water exists beyond permissible level so as to adsorb the $\mathrm{As}(\mathrm{V})$ from water. Ultraviolet radiation can be used to catalyze the process of oxidation of $\mathrm{As}(\mathrm{III})$ in presence of other oxidants like oxygen (Young, 1996).

\subsubsection{In-situ oxidation}

In-situ oxidation of arsenic and iron in the aquifer has been tried under DPHE (2001) Danida Arsenic Mitigation Pilot Project. The aerated tube well water is stored in a tank and released back into the aquifers through the tube well by opening a valve in a pipe connecting the water tank to the tube well pipe under the pump head. The dissolved oxygen content in water oxidizes As(III) to less mobile $\operatorname{As}(\mathrm{V})$ and also the ferrous iron in the aquifer to ferric iron causing a reduction in arsenic content of tube well water. Experimental results show that arsenic in the tube well water following in-situ oxidation is reduced to about half due to underground precipitation and adsorption on ferric iron.

\subsubsection{Passive sedimentation}

Passive sedimentation also received considerable attention in rural areas because of rural people's habit of drinking stored water from pitchers. Oxidation of water during collection and subsequent storage in houses may cause a reduction in arsenic concentration in stored water (Bashi Pani). Experiments conducted in Bangladesh showed zero to high reduction in arsenic content by passive sedimentation. Arsenic reduction by plain sedimentation appears to be dependent on water quality particularly the presence of precipitating iron in water. Ahmed et al. (2000) showed that more than $50 \%$ reduction in arsenic content is possible by sedimentation of tube well water containing $380-480 \mathrm{mg} \mathrm{L}^{-1}$ of alkalinity as $\mathrm{CaCO}_{3}$ and $8-12 \mathrm{mg} \mathrm{L}^{-1}$ of iron but cannot be relied to reduce arsenic to desired level. Most studies showed a reduction of zero to $25 \%$ of the initial concentration of arsenic in ground water. However, in rapid assessment of technologies, passive sedimentation failed to reduce arsenic to the desired level (BAMWSP, DFID, Water Aid, 2001).

\subsection{Biological oxidation}

The biological oxidation of iron and manganese as a treatment method for arsenic removal is a relatively new method. The process is based upon the fact that ground waters contaminated with arsenic are usually reducing and containing concentrations of iron and manganese. The filters for the removal of iron and manganese operating with pre aeration eventually are populated with iron and manganese oxidizing bacteria, which can oxidize very efficiently As(III), which then can be adsorbed on iron and manganese oxides and get removed from the water. Katsoyiannis et al. (2002) have applied biological iron and manganese oxidation to remove $\mathrm{As}(\mathrm{III})$ and $\mathrm{As}(\mathrm{V})$ from ground water without the use of chemical oxidizing agents, apart from oxygen and bacteria. The application of biological iron or manganese oxidation results in the formation of insoluble products (iron or manganese oxides), which are subsequently removed from water by filtration (Mouchet, 1992). If arsenic is 
simultaneously present in the water, it can be removed by sorption onto the produced oxides, which progressively creates a natural (biogenic) coating on the filter medium. Therefore, the application of this method for the removal of arsenic has been termed "biological adsorptive filtration" (Zouboulis and Katsoyiannis et al., 2002c).

Katsoyiannis and Zouboulis (2004a) studied application of biological processes for the removal of arsenic from ground waters and reported that both inorganic forms of arsenic can be efficiently treated in the concentration range $50-200 \mu \mathrm{g} \mathrm{L}^{-1}$. In addition, the oxidation of trivalent arsenic was found to be catalyzed by bacteria, leading to enhanced overall arsenic removal, because arsenic in the form of $\mathrm{As}(\mathrm{III})$ cannot be efficiently sorbed onto iron oxides. The method can find application in treatment of ground waters with elevated concentrations of iron and arsenic. In an another study, Katsoyiannis and Zouboulis (2004b) have studied biological treatment of $\mathrm{Mn}(\mathrm{II})$ and $\mathrm{Fe}(\mathrm{II})$ containing ground water in up flow filtration units. The oxidation processes were mediated by specific bacteria, namely the Leptothrix ochracea and Gallionella ferruginea, which belong to the general category of manganese and iron oxidizing bacteria. The rates of manganese and iron oxidation were found several orders of magnitude greater than the respective rates for abiotic oxidation and the rates of bacterially mediated oxidation of iron was faster than manganese oxidation, presenting half-lives of reactions 0.9 and $3.98 \mathrm{~min}$, respectively. The fast rates of reaction rendered the treatment method quite economic and environmental friendly, because no additional use of chemical reagents is required in the process.

The kinetics of bacterial As(III) oxidation and subsequent $\mathrm{As}(\mathrm{V})$ removal by sorption onto biogenic manganese oxides during ground water treatment has been studied by Katsoyiannis et al. (2004). Their findings indicated that the rate of oxidation of $\mathrm{As}$ (III) was significantly higher than the rates reported for abiotic As(III) oxidation by manganese oxides, supporting the indication that bacteria play an important role in both the oxidation of As(III) and the generation of reactive manganese oxide surfaces for the removal of $\mathrm{As}(\mathrm{III})$ and $\mathrm{As}(\mathrm{V})$ from solution. Thus, bacteria play an important role in both the As(III) oxidation and the generation of reactive manganese oxide surfaces for the removal of dissolved $\mathrm{As}(\mathrm{III})$ and $\mathrm{As}(\mathrm{V})$. The following sequence of reactions have been found to occur in the treatment system: (a) oxidation of $\mathrm{Mn}$ (II) to $\mathrm{Mn}(\mathrm{IV})$ and $\mathrm{Fe}(\mathrm{II})$ to $\mathrm{Fe}(\mathrm{III})$, (b) oxidation of $\mathrm{As}(\mathrm{III})$ to $\mathrm{As}(\mathrm{V})$, (c) precipitation of manganese(IV) oxides, (d) abiotic oxidation of As(III) by manganese(IV) oxides, and (e) As(V) sorption by manganese(IV) oxides, where steps $\mathrm{a}$ and $\mathrm{b}$ are biotic and steps $\mathrm{c}-\mathrm{e}$ are abiotic.

The presence of phosphates at concentrations of around $600 \mu \mathrm{g} / \mathrm{L}$ had an adverse effect on As(III) removal (competitive adsorption) and reduced the overall removal efficiency from 80 to $30 \%$, although it did not affect the oxidation of As(III). The bacterial species responsible for the reactions occurring in the treatment system were G. ferruginea and L. ochracea (Zouboulis and Katsoyiannis et al., 2002c). However, several other species of bacteria, belonging mainly to the Leptothrix or Sphaerotilus groups, have also been reported to oxidize manganese (Czekalla et al., 1985; Mouchet, 1992) and play an important role in both the $\mathrm{As}(\mathrm{III})$ oxidation and the generation of reactive manganese oxide surfaces for the removal of dissolved $\mathrm{As}(\mathrm{III})$ and $\mathrm{As}(\mathrm{V})$. These bacteria, which are indigenous in most ground waters, require relatively stringent conditions to oxidize the soluble forms of manganese. In particular, they demand an aerobic environment [DO $>3 \mathrm{mg} \mathrm{L}^{-1}$ ] and redox (Eh) values between 300 and $400 \mathrm{mV}$. Occasionally, to accelerate the initiation of the manganese oxidation procedure, the filter medium (i.e., sand or polystyrene beads) can be coated with synthetic $\mathrm{MnO}_{2}$ (Mouchet, 1992).
Katsoyiannis and Zouboulis (2006) have reviewed the use of iron and manganese oxidizing bacteria for the combined removal of iron, manganese and arsenic from contaminated ground water. The arsenic removal efficiency is reported to be higher by iron oxidizing bacteria than manganese oxidizing bacteria. The difference in the removal efficiency can be attributed to the fact that iron oxides are efficient adsorbents regarding the removal of arsenic, presenting a strong tendency to create surface complexes with arsenic ions, whereas the use of manganese oxides is not equally efficient. It has also been reported that with the application of biological iron oxidation, the arsenic removal efficiency was not affected by the different initial arsenic concentrations and the final concentration of arsenic was always below $10 \mu \mathrm{g} \mathrm{L}^{-1}$. The rates of oxidation of iron, manganese and arsenic are faster than those reported for physicochemical oxidation, indicating the catalytic role of bacteria in removing arsenic.

The application of the specific treatment technology offers several advantages over conventional physico-chemical treatment methods. Efficient removal of arsenic can be achieved without the use of any chemicals for oxidation or sorption processes. It should also be noted that most physico-chemical sorptive treatment methods present the drawback of adsorbate exhaustion (breakthrough). In order to continue the operation, the consumed adsorbing materials need either regeneration or replacement. However, in biological oxidation, the adsorbents are continuously produced by the biological oxidation of dissolved iron or manganese, which is also present in ground water. Therefore, the need for regeneration or replacement of the filter media is not required. Once set in effective operation, the only consideration would be to perform the backwashing action periodically, in order to avoid filter clogging and to remove the excess sludge (Katsoyiannis and Zouboulis, 2006).

The method has been applied successfully in industrial area of Thessaloniki (Katsoyiannis and Katsoyiannis, 2006), drinking water supply wells (Katsoyiannis et al., 2007) and in the city of Malgara in Northern Greece (Katsoyiannis et al., 2008a,b). The method can find broader application in South East Asia because of its several advantages over other conventional physico-chemical treatment methods.

\subsection{Co-precipitation}

Co-precipitation has been the most frequently used method to treat arsenic contaminated water in numerous pilot- and fullscale applications. Water treatment with coagulants such as alum $\left[\mathrm{Al}_{2}\left(\mathrm{SO}_{4}\right)_{3} \cdot 18 \mathrm{H}_{2} \mathrm{O}\right]$, ferric chloride $\left[\mathrm{FeCl}_{3}\right]$ and ferric sulfate $\left[\mathrm{Fe}_{2}\left(\mathrm{SO}_{4}\right)_{3} \cdot 7 \mathrm{H}_{2} \mathrm{O}\right]$ are effective in removing arsenic from water (Edwards, 1994; Hering et al., 1996, 1997; Chen et al., 1999). Ferric salts have been found to be more effective in removing arsenic than alum on a weight basis and effective over a wider $\mathrm{pH}$ range (Cheng et al., 1994; Hering et al., 1997). This technology can typically reduce arsenic concentrations to less than $10 \mu \mathrm{g} \mathrm{L}^{-1}$ and the doses of ferric salt below $10 \mathrm{mg} \mathrm{L}^{-1}$ (Pontius, 1995). During the flocculation process, all kinds of micro-particles and negatively charged ions are attached to the flocs by electrostatic attachment. Arsenic is also adsorbed onto coagulated flocs. As trivalent arsenic occurs in non-ionized form, it is not subject to significant removal. Oxidation of $\mathrm{As}(\mathrm{III})$ to $\mathrm{As}(\mathrm{V})$ is thus required as a pre-treatment for efficient removal. This can be achieved by addition of bleaching powder (chlorine) or potassium permanganate or ozone.

Coagulation-flocculation can only be used successfully when the flocs are separated out reliably and when most of the coagulant is also removed. In general, the following three chemical precipitation processes are normally used (Chwirka et al., 2000; Fields 
et al., 2000b; Jekel and Seith, 2000; Madiec et al., 2000; Sancha, 2000):

i) Enhanced Lime Softening,

ii) Conventional gravity coagulation/filtration, and

iii) Coagulation Assisted Microfiltration.

Fig. 2 shows flow diagram for a generic precipitation/filtration process. Dashed lines and boxes indicate optional processes.

\subsubsection{Enhanced Lime Softening}

Lime softening solely for arsenic removal is uneconomical and is generally considered cost-prohibitive. However, for water systems that use lime softening to reduce hardness, the process can be enhanced for arsenic removal. To remove $\operatorname{As}(\mathrm{V})$, additional lime is added to increase the $\mathrm{pH}$ value above 10.5 units. In this range magnesium hydroxide precipitates and $\mathrm{As}(\mathrm{V})$ is removed by coprecipitation with it. $\mathrm{As}(\mathrm{V})$ removal by co-precipitation with calcium carbonate (i.e., below a pH of 10.5 ) is poor (less than $10 \%$ ).

The amount of waste residual produced by lime softening is dependent on the hardness removed. While the total volume of waste produced from lime softening is typically higher than that produced by coagulation/filtration and co-precipitation processes, the arsenic concentration in the sludge is generally lower because more solids are produced. Typical solids concentrations are $1-4 \%$ arsenic. Prior to disposal, this waste residual will require thickening and dewatering, most likely via mechanical devices. Previous studies have indicated that typical lime sludge will not exceed toxicity characteristics limits, enabling it to be disposed of in a municipal solid waste landfill (Fields et al., 2000a,b).

\subsubsection{Conventional Gravity Coagulation/Filtration}

Coagulation/filtration processes for removal of $\mathrm{As}(\mathrm{V})$ from water involves the adsorption of $\mathrm{As}(\mathrm{V})$ to ferric hydroxide precipitate. The $\mathrm{As}(\mathrm{V})$ becomes entrapped as the particle continues to agglomerate. As(III) is not effectively removed because of its overall neutral charge under natural $\mathrm{pH}$ conditions. Therefore, pre-oxidation is recommended. The efficiency and economics of the system depends on water characteristics, such as natural organic matter, and contingent upon several factors, including the type and dosage of coagulant, mixing intensity and $\mathrm{pH}$. In general, however, optimized coagulation-filtration systems are capable of achieving over $90 \%$ removal of $\mathrm{As}(\mathrm{V})$ and producing water with less than $5 \mu \mathrm{g} \mathrm{L}{ }^{-1}$ of $A s(V)$. Influent $A s(V)$ levels do not appear to impact the effectiveness of this treatment process.

Iron-based coagulants, including ferric sulfate and ferric chloride, are more effective for removing $\mathrm{As}(\mathrm{V})$ than their aluminumbased counterparts. This is because iron hydroxides are more stable than aluminum hydroxides in the $\mathrm{pH}$ range 5.5-8.5. A fraction of the aluminum remains as a soluble complex, which is incapable of adsorbing $\mathrm{As}(\mathrm{V})$ and can pass through the filtration stage. The optimal $\mathrm{pH}$ ranges for coagulation with aluminum and ferric salts are 5-7 and 5 to 8 , respectively. At $\mathrm{pH}$ values above 7 , the removal performance of aluminum-based coagulants drops markedly. Feed water $\mathrm{pH}$ should be adjusted to the appropriate range prior to coagulant addition. Post-filtration $\mathrm{pH}$ adjustment may be necessary to optimize corrosion control and comply with other regulatory requirements.

\subsubsection{Coagulation assisted microfiltration}

Coagulation-assisted microfiltration uses the same coagulation process described above. However, instead of the granular media filtration step, the water is forced through a semi-permeable membrane by a pressure differential. The membrane retains the $\mathrm{As}(\mathrm{V})$ laden floc formed in the coagulation step. The use of preengineered coagulation assisted microfiltration package plants is a realistic possibility for new installations where water quality precludes the use of sorption treatment. The membrane must be periodically backwashed to dislodge solids and restore hydraulic capacity. Backwash water is typically a high-volume, low solids (less than $1.0 \%$ ) waste stream. The specific amount of solids will depend on several factors, including coagulant type, dosage, filter run length and ambient solids concentration.

The co-precipitation based arsenic removal techniques have been applied for the following system:

- Central Arsenic Removal Plant (ARP) attached with tube wells for piped water supply,

- Arsenic Removal Plant (ARP) attached with Hand Pump, and

- Domestic Arsenic Removal Units using Earthen Pots, Plastic Buckets, Bucket Treatment Units, Modified BTUs, Stevens Institute Technology, Fill and Draw Units, Naturally Occurring Iron, etc.

2.4.3.1. Arsenic Removal Plant attached to hand pump/tube well. Hand pump/tube well attached Arsenic Removal Plants (ARP) operating on co-precipitation technique have been developed by All India Institute of Hygiene and Public Health (AIIH\&PH), Kolkata, West Bengal. As per present market value the hand pump/tube well attached Arsenic Removal Plants are costing Rs. 40,000/- (brick masonry) and Rs. $45,000 /-$ (MS fabrication). The treatment capacity of the unit is $650 \mathrm{lts} / \mathrm{h}$. Average number of beneficiaries per ARP is 150 families. A contribution of Rs. 5/- per family per month is necessary for operation and maintenance of the plant. The units have been found effective in removing 90\% arsenic from tube well water having initial arsenic concentration of $300 \mu \mathrm{g} / \mathrm{L}$. The treatment process involves addition of sodium hypochloride $\left(\mathrm{Cl}_{2}\right)$ and aluminum alum in diluted form, mixing, flocculation, sedimentation and up flow filtration in a compact unit.

Hand pump attached arsenic removal plants could work satisfactorily if communities are involved with the programme. If usergroups are trained and user-communities are formed for operation and maintenance, the ARPs could function satisfactorily. A sense of ownership needs to be generated amongst the user-group. A token subscription by user-family per month would help in upkeepment of the plant as well as for media replacement as and when necessary.

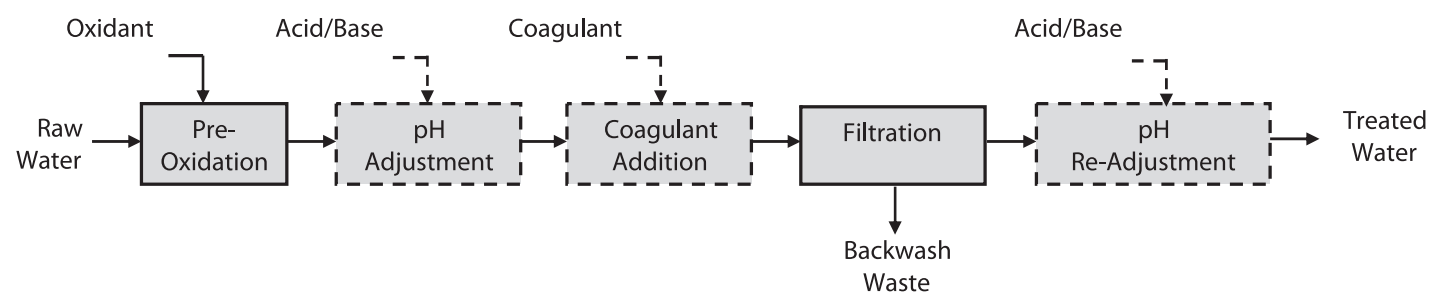

Fig. 2. Flow Diagram for Generic Precipitation/Filtration Process. 
The above co-precipitation methodology has also been adopted for development of domestic arsenic removal units. A plastic bucket and a filter are required for operation. The filter unit may be earthen, plastic, ferro-cement etc. The candle for filter may be ceramics or burnt clay (Tripura type). The cost of the filter varies from Rs. 80/- to 200/-.

2.4.3.2. Bucket Treatment Unit (BTU). The Bucket Treatment Unit (BTU) developed by Department of Public Health Engineering (DPHE), Bangladesh and Danish International Development Agency (Danida) (DPHE-Danida Arsenic Mitigation Pilot Project, 2001 ) is based on the principles of coagulation, co-precipitation and adsorption processes. It consists of two buckets, each $20 \mathrm{~L}$ capacity, placed one above the other. Chemicals are mixed manually with arsenic contaminated water in the upper red bucket by vigorous stirring with a wooden stick for 30-60 s and then flocculated by gentle stirring for about $90 \mathrm{~s}$. The mixed water is then allowed to settle for $1-2 \mathrm{~h}$. The water from the top red bucket is then allowed to flow into the lower green bucket via plastic pipe and a sand filter installed in the lower bucket. The flow is initiated by opening a valve fitted slightly above the bottom of the red bucket to avoid inflow of settled sludge in the upper bucket. The lower green bucket is practically a treated water container.

The DPHE-Danida project in Bangladesh distributed several thousands BTU units in rural areas of Bangladesh. These units are based on chemical doses of $200 \mathrm{mg} \mathrm{L}^{-1}$ aluminum sulfate and $2 \mathrm{mg} \mathrm{L}^{-1}$ of potassium permanganate supplied in crushed powder form. The units were reported to have very good performance in arsenic removal in both field and laboratory conditions (Sarkar et al., 2000; Kohnhorst and Paul, 2000). Extensive study of DPHEDanida BTU under BAMWSP, DFID, Water Aid (2001) rapid assessment program showed mixed results. In many cases, the units under rural operating conditions fail to remove arsenic to the desired level of $50 \mu \mathrm{g} \mathrm{L}^{-1}$ in Bangladesh. Poor mixing and variable water quality particularly $\mathrm{pH}$ of ground water in different locations of Bangladesh appeared to be the cause of poor performance in rapid assessment.

2.4.3.3. Modified Bucket Treatment Unit (modified BTU). Bangladesh University of Engineering and Technology (BUET) modified the BTU and obtained better results by using $100 \mathrm{mg} \mathrm{L}^{-1}$ of ferric chloride and $1.4 \mathrm{mg} \mathrm{L}^{-1}$ of potassium permanganate in modified BTU units. The arsenic contents of treated water were mostly below $20 \mu \mathrm{g} \mathrm{L}^{-1}$ and never exceeded $37 \mu \mathrm{g} \mathrm{L}^{-1}$ while arsenic concentrations of tube well water varied between 375 and $640 \mu \mathrm{g} \mathrm{L}^{-1}$. The BTU is a promising technology for arsenic removal at household level at low cost. It can be built by locally available materials and is effective in removing arsenic if operated properly.

2.4.3.4. Stevens Institute Technology. This technology also uses two buckets, one to mix chemicals (iron sulfate and calcium hypochloride) and the other to separate flocs by the processes of sedimentation and filtration. The chemicals form visible large flocs on mixing by stirring with stick. Rapid assessment showed that the technology was effective in reducing arsenic levels to less than $50 \mu \mathrm{g} \mathrm{L}^{-1}$ in case of $80-95 \%$ of the samples tested (BAMWSP, DFID, WaterAid, 2001). The sand bed used for filtration is quickly clogged by flocs and requires washing at least twice a week.

2.4.3.5. BCSIR filter unit. Bangladesh Council of Scientific and Industrial Research (BCSIR) have developed an arsenic removal system, which uses the process of coagulation/co-precipitation with an iron based chemical followed by sand filtration. However, the performance of the unit could not be evaluated.
2.4.3.6. Fill and Draw Units. It is a community type treatment unit designed and installed under DPHE-Danida Arsenic Mitigation Pilot Project. It is a 600 L capacity (effective) tank with slightly tapered bottom for collection and withdrawal of settled sludge. The tank is fitted with a manually operated mixer with flat-blade impellers. The tank is filled with arsenic contaminated water and required quantity of oxidant and coagulant are added to the water. The water is then mixed for $30 \mathrm{~s}$ by rotating the mixing device at the rate of $60 \mathrm{rpm}$ and left overnight for sedimentation. The water takes some times to become completely still which helps flocculation. The floc formation is caused by the hydraulic gradient of the rotating water in the tank. The settled water is then drawn through a pipe fitted at a level, few inches above the bottom of the tank and passed through a sand bed and finally collected through a tap for drinking purpose. The mixing and flocculation processes in this unit are better controlled to effect higher removal of arsenic. The experimental units installed by DPHE-Danida project are serving the clusters of families and educational institutions.

2.4.3.7. Naturally occurring iron. The use of naturally occurring iron precipitates in ground water in Bangladesh is a promising method of removing arsenic. It has been found that hand tube well water in $65 \%$ of the area in Bangladesh contains iron in excess of $2 \mathrm{mg} \mathrm{L}^{-1}$ and in many acute iron problem areas the concentration of dissolved iron is higher than $15 \mathrm{mg} \mathrm{L}^{-1}$. Although no good correlation between concentrations of iron and arsenic has been reported, iron and arsenic have been found to co-exist in ground water. Most of the tube well water samples satisfying Bangladesh Drinking Water Standard for iron $\left(1 \mathrm{mg} \mathrm{L}^{-1}\right)$ also satisfy the standard for arsenic $\left(50 \mu \mathrm{g} \mathrm{L}^{-1}\right)$. Only about $50 \%$ of the samples having iron content 1-5 $\mathrm{mg} \mathrm{L}^{-1}$ satisfy the standard for arsenic while $75 \%$ of the samples having iron content $>5 \mathrm{mg} \mathrm{L}^{-1}$ are unsafe for having high concentration of arsenic.

The iron precipitates $\left[\mathrm{Fe}(\mathrm{OH})_{3}\right]$ formed by oxidation of dissolved iron $\left[\mathrm{Fe}(\mathrm{OH})_{2}\right]$ present in ground water have the affinity for the removal of arsenic. Only aeration and sedimentation of tube well water rich in dissolved iron has been found to remove arsenic. The Iron Removal Plants (IRPs) in Bangladesh constructed on the principles of aeration, sedimentation and filtration in a small unit have been found to remove arsenic without any added chemicals. The conventional community type IRPs, depending on the operating principles, more or less work as Arsenic Removal Plants (ARPs) as well. A study suggests that $\mathrm{As}(\mathrm{III})$ is oxidized to $\mathrm{As}(\mathrm{V})$ in the IRPs to facilitate higher efficiency in arsenic removal in IRPs (Dahi and Liang, 1998). The efficiency of these community type Fe-As removal plants can be increased by increasing the contact time between arsenic species and iron flocs. Community participation in operation and maintenance at the local level is absolutely essential for effective use of these plants.

Some medium scale $\mathrm{Fe}-$ As removal plants of capacities 2000-3000 $\mathrm{m}^{3} \mathrm{~d}^{-1}$ have been constructed for water supplies in district towns based on the same principle. The treatment processes involved in these plants include aeration, sedimentation and rapid sand filtration with provision for addition of chemical, if required. These plants are working well except that treated water requirement for washing the filter beds is very high. Operations of small and medium size IRP-cum-ARPs in Bangladesh suggest that arsenic removal by co-precipitation and adsorption on natural iron flocs has good potential.

\subsection{Adsorption}

Adsorption technology has been widely used to treat ground water containing arsenic. The technology typically can reduce arsenic concentrations to less $10 \mu \mathrm{g} \mathrm{L}^{-1}$. Its effectiveness is sensitive 
to a variety of untreated water contaminants and characteristics. The adsorption media is usually packed into a column. As the contaminated water is passed through the column, contaminants are adsorbed. When adsorption sites become filled, the column must be regenerated or disposed of and replaced with new media.

The following media are commonly used for removal of arsenic through adsorption technique:

i) Activated alumina (AA),

ii) Iron Based Sorbents (IBS) - Granular Ferric Hydroxide, Zero Valent Iron, Iron Coated Sand, etc.,

iii) Indigenous Filters and Cartridges, and

iv) Other Miscellaneous Adsorbents

The efficiency of sorptive media depends on the use of oxidizing agent as aids to sorption of arsenic. Saturation of media by different contaminants and components of water takes place at different times of operation depending on the specific sorption affinity of the medium to the given component.

\subsubsection{Activated alumina $(A A)$}

Activated alumina was the first adsorptive medium to be successfully applied for the removal of arsenic from water supplies (EPA, 2000a,b). It is a porous, granular material having good sorption properties. The media, aluminum trioxide, is prepared through the dehydration of aluminum hydroxide at high temperatures. AA grains have a typical diameter of $0.3-0.6 \mathrm{~mm}$ and a high surface area for sorption. The removal of $\mathrm{As}(\mathrm{V})$ by $\mathrm{AA}$ adsorption can be accomplished by continuously passing water under pressure through one or more beds packed with AA media. Fig. 3 shows a typical process flow diagram for the adsorption process. Dashed lines and boxes indicate optional streams and processes.

The reported adsorption capacity of AA ranges from 0.003 to $0.112 \mathrm{~g}$ of arsenic per gram of AA. It is available in different mesh sizes and its particle size affects contaminant removal efficiency. Up to 23,400 bed volumes of wastewater can be treated before $A A$ requires regeneration or disposal and replacement with new media. The selectivity of AA towards As(III) is poor, owing to the overall neutral molecular charge at $\mathrm{pH}$ levels below 9.2. Therefore, pre-oxidation of $\mathrm{As}(\mathrm{III})$ to $\mathrm{As}(\mathrm{V})$ is critical. Several different studies have established the optimum $\mathrm{pH}$ range as 5.5-6.0, and demonstrated greater than $98 \%$ arsenic removal under these conditions (Rosenblum and Clifford, 1984; EPA, 2000a,b; 2003a,b). AA column runs operated under acidic $\mathrm{pH}$ conditions are 5-20 times longer than under natural $\mathrm{pH}$ conditions (6.0-9.0). The arsenic removal capacity of activated alumina is $\mathrm{pH}$ sensitive and therefore requires pre- and post- $\mathrm{pH}$ adjustment using caustic soda and sulfuric acid. Activated alumina is also capable of being chemically regenerated for repetition of treatment cycles using the same corrosive chemicals as those used for $\mathrm{pH}$ adjustment in the treatment process. Employing $\mathrm{pH}$ adjustment, therefore, generally provides cost advantages regardless of whether the media is regenerated or replaced. Because the $\mathrm{pH}$ adjustment chemicals are usually the same chemicals that are use for regeneration, it is generally advantageous to couple regeneration with $\mathrm{pH}$ adjustment systems when the media can be regenerated (EPA, 2003b).

Several constituents can interfere with the adsorption process, either by competing for adsorption sites or clogging the media with particulate matter. The presence of suspended solids in the feed water could gradually clog the media and therefore prefiltration is recommended for sources where the turbidity exceeds 0.3 NTU. AA media can either be regenerated on-site or disposed of and replaced with fresh media. Regeneration of saturated alumina is carried out by exposing the medium to $4 \%$ caustic soda, $\mathrm{NaOH}$, either in batch or by flow through the column resulting in high arsenic contaminated caustic wastewater. Onsite regeneration of AA media typically produces 37 to 47 bed volumes of caustic soda waste (EPA, 2000a,b). The residual caustic soda is then washed out and the medium is neutralized with $2 \%$ solution of sulfuric acid rinse. During the process about $5-10 \%$ alumina is lost and the capacity of the regenerated medium is reduced by $30-40 \%$. The activated alumina needs replacement after 3-4 regeneration. Like coagulation process, pre-chlorination improves the column capacity dramatically. The cost of the activated alumina in India is about Rs. 100/- to Rs. 110/- per kg. Bengal Engineering College, Shibpur has developed both hand pump attached and domestic models. Various hand pump attached arsenic removal plants with activated alumina as adsorbent have been installed in West Bengal (India) and Bangladesh through various initiatives.

The technologies and market for alumina-based adsorptive media is continuously expanding. There are several emerging proprietary media, commonly referred to as modified AA, which contain alumina in a mixture with other substances such as iron and sulfur. In some instances, these media have greater overall adsorptive capacities, enhanced selectivity towards arsenic, and/or greater overall operational flexibility than conventional AA, thus making them more cost-effective. Some of the activated alumina based sorptive media include BUET Activated Alumina, Alcan Enhanced Activated Alumina, Arsenic Removal Units (ARUs) of Project Earth Industries Inc., USA, and Apyron Arsenic Treatment Units.

The BUET and Alcan activated alumina have been extensively tested in field condition in different parts of Bangladesh and found very effective in arsenic removal (BAMWSP, DFID, Water Aid, 2001). The Arsenic Removal Units (ARUs) of Project Earth Industries Inc., USA used hybrid aluminas and composite metal oxides as adsorption media and were able to treat 200-500 Bed Volume (BV) of water containing $550 \mathrm{mg} \mathrm{L}^{-1}$ of arsenic and $14 \mathrm{mg} \mathrm{L}^{-1}$ of iron (Ahmed et al., 2000). The Apyron Technologies Inc. (ATI) also uses inorganic granular metal oxide based media that can selectively remove $\mathrm{As}(\mathrm{III})$ and $\mathrm{As}(\mathrm{V})$ from water. The Aqua-Bind $\mathrm{TM}$ arsenic media used by ATI consist of non-hazardous aluminum oxide and manganese oxide for cost-effective removal of arsenic. The proponents claimed that the units installed in India and Bangladesh consistently reduced arsenic to less than $10 \mu \mathrm{g} \mathrm{L}^{-1}$.

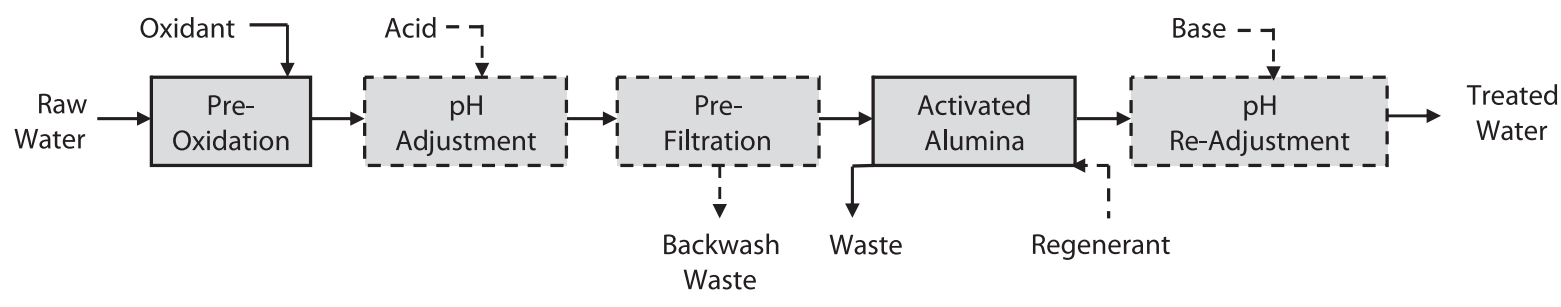

Fig. 3. Activated Alumina Process Flow Diagram. 
Recently, Ike et al. (2008) have examined the efficacy of activated alumina in removing arsenic through bacterial oxidation of As(III) with a chemical adsorption process. By acclimation to As(III) of high concentrations, a mixed culture of heterotrophic bacteria with high As(III)-oxidizing activity was obtained from a soil sample that was free from contamination. The mixed culture contained several genera of heterotrophic As(III)-oxidizing and arsenictolerant bacteria: Haemophilus, Micrococcus, and Bacillus. Arsenic removal by activated alumina was greatly enhanced by bacterial oxidation of $\mathrm{As}(\mathrm{III})$ to $\mathrm{As}(\mathrm{V})$. The isotherms of $\mathrm{As}(\mathrm{III})$ and $\mathrm{As}(\mathrm{V})$ onto activated alumina verified that bacterial As(III) oxidation is a helpful pre-treatment process for the conventional adsorption process for arsenic removal.

\subsubsection{Iron based sorbents (IBS)}

Adsorption on IBS is an emerging treatment technique for arsenic removal. Examples of IBS products currently available in the market include granular ferric hydroxide, zero valent iron, iron coated sand, modified iron and iron oxide based adsorbents. The sorption process has been described as chemisorption (Selvin et al., 2000), which is typically considered to be irreversible. It can be applied in fixed bed pressure columns, similar to those for AA. The development of iron based sorbents for arsenic removal has been considered as one of the most promising solution, leading to the development of adsorbents with better performance than activated alumina (Jekel, 1994; Driehaus et al., 1998; Lackovic et al., 2000; Farrell et al., 2001; Su and Puls, 2001, 2003; Manning et al., 2002a,b; Melitas et al., 2002; Nikolaidis et al., 2003; Hussm and Munir, 2007).

The studies conducted with IBS media have revealed that the affinity of this media for arsenic is strong under natural $\mathrm{pH}$ conditions, relative to AA. This feature allows IBS to treat much higher bed volumes without the need for $\mathrm{pH}$ adjustment. However, similar to AA, optimal IBS performance is obtained at lower $\mathrm{pH}$ values. Phosphate has been shown to compete aggressively with $\mathrm{As}(\mathrm{V})$ for adsorption sites. Each $0.5 \mathrm{mg} \mathrm{L}^{-1}$ increase in phosphate above $0.2 \mathrm{mg} \mathrm{L}^{-1}$ reduce adsorption capacity by roughly $30 \%$. The exhausted IBS media can be disposed of in a municipal solid waste landfill (MacPhee et al., 2001).

The Technical University, Berlin, Germany has developed an effective Granular Ferric Hydroxide (GFH) adsorbent for arsenic removal from natural water (Driehaus et al., 1998). The adsorbent has a specific surface area of $250-300 \mathrm{~m}^{2} \mathrm{~g}^{-1}$ and a porosity of $75-80 \%$. The bulk density of GFH saturated with water is $1.32 \mathrm{~g} \mathrm{~cm}^{-3}$. The grain size ranges from 0.2 to $2.0 \mathrm{~mm}$ with all the pores filled with water leading to high density of the available adsorption sites and a high adsorption capacity. The adsorbent has been successfully applied in simple fixed bed reactors, similar to those of activated alumina or activated carbon. The specific capacity of fixed bed adsorbers with GFH depends on $\mathrm{pH}$, phosphate content and the raw water concentration of $\mathrm{As}(\mathrm{V})$. It has been shown that in technical scale adsorbers more than 50,000 bed volumes can be treated and filter rates of $15 \mathrm{~m} \mathrm{~h}^{-1}$ are possible. The residue of the technique is a solid waste with residual mass in the range $5-25 \mathrm{~g} \mathrm{~m}^{-3}$ treated water (Driehaus et al., 1998). The adsorbent has been successfully marketed under the trade name $\mathrm{GEH}^{\circledR}$. The technology requires only a small contact time between 3 and $10 \mathrm{~min}$, whereas the treatment capacities are up to 150,000 bed volumes. The average treatment costs, including media exchange service and disposal is 0.04 EURO per $\mathrm{m}^{3}$ treated water (Driehaus, 2002). M/s Pal Trockner (P) Ltd, India and M/s Sidko Limited, Bangladesh installed several GFH based arsenic removal units in India and Bangladesh. The unit requires iron removal as pretreatment to avoid clogging of filter bed. The proponents of the unit claim to have high treatment capacity between 40,000 and
60,000 bed volumes, until the permissible limit of $0.01 \mathrm{mg} \mathrm{L}^{-1}$ is exceeded and the unit produces non-toxic spent granular ferric hydroxide. As iron content in ground water is generally high, all hand pump attached arsenic removal plants working under adsorption principles also require regular backwashing/cleaning for removal of arrested iron particles. Such backwashing need to be done periodically for optimal operation of the units.

The removal of arsenic by zero valent iron (ZVI) has received increased attention during recent years due to high arsenic removal capacity of ZVI. Several research groups have used ZVI for the removal of arsenic from water (Lackovic et al., 2000; Farrell et al., 2001; Su and Puls, 2001, 2003; Manning et al., 2002a,b; Melitas et al., 2002; Nikolaidis et al., 2003) and reported that arsenic species are removed by zero valent iron through adsorption on iron oxides. Column experiments have been conducted to evaluate the effectiveness of ZVI for arsenic removal (Melitas et al., 2002; Lackovic et al., 2000; Nikolaidis et al., 2003; Su and Puls, 2003). Melitas et al. (2002) reported that the removal rates of arsenic were up to 10 times faster near the inlet end of the iron column than near the effluent end and attributed this to rapid oxidation of ZVI by small amounts of DO in the influent. On the other hand, Ramaswami et al. (2001) reported that the presence of air in batch reactors hindered arsenic removal by ZVI. All the column experiments were conducted under anoxic conditions and at relatively long hydraulic contact time. The results indicate that a batch-mixed iron decantation system is effective in the treatment of water containing arsenic in the range of $200-2000 \mu \mathrm{g} \mathrm{L}^{-1}$ at contact times of $30 \mathrm{~min}-3 \mathrm{~h}$, with iron dose ranging from 2500 to $625 \mathrm{mg} \mathrm{L}^{-1}$.

Bang et al. (2005) conducted batch and column experiments to investigate the effect of DO and pH on arsenic removal with ZVI and reported that arsenic removal was significantly affected by DO content and $\mathrm{pH}$ of the solution. Under oxic conditions, the removal of $\mathrm{As}(\mathrm{V})$ was found to be faster than that of As(III). More than $99.8 \%$ of the $\mathrm{As}(\mathrm{V})$ was removed whereas $82.6 \%$ of the $\mathrm{As}(\mathrm{III})$ was removed at pH 6 after $9 \mathrm{~h}$ of mixing. In the presence of oxygen, large amounts of ferric hydroxide precipitate were formed rapidly from ZVI filings and both $\mathrm{As}(\mathrm{V})$ and $\mathrm{As}(\mathrm{III})$ were removed by the iron hydroxide precipitate through adsorption. Because iron hydroxide has a higher adsorption capacity for $\mathrm{As}(\mathrm{V})$ than for As(III) at neutral $\mathrm{pH}$, $\mathrm{As}(\mathrm{V})$ removal was greater than that of As(III) (Meng et al., 2000). It is well known that the extent of $\mathrm{As}(\mathrm{V})$ adsorption decreases with increase in $\mathrm{pH}$ from 5 to 10 . When the solution was purged with nitrogen gas to remove DO, less than $10 \%$ of the $\mathrm{As}(\mathrm{III})$ and $\mathrm{As}(\mathrm{V})$ was removed. The presence of $\mathrm{DO}$ and low $\mathrm{pH}$ increased the rate of iron corrosion and arsenic removal in both batch and column experiments and the removal of arsenic was mainly attributed to adsorption on iron hydroxides produced from the oxic corrosion of zero valent iron. The authors concluded that a filtration system consisting of an iron column and a sand filter can be used for the treatment of arsenic in drinking water in the presence of DO and in a near neutral $\mathrm{pH}$ range (Bang et al., 2005).

The reaction of ZVI with dissolved oxygen leads to the formation of reactive intermediates (e.g., $\mathrm{HO}_{2} / \bullet^{\circ} \mathrm{O}_{2^{-}}, \mathrm{H}_{2} \mathrm{O}_{2}, \cdot \mathrm{OH}$ ) and $\mathrm{Fe}(\mathrm{II}) . \mathrm{Fe}(\mathrm{II})$ is subsequently oxidized to $\mathrm{Fe}(\mathrm{III})$ and forms hydrous ferric oxides with large sorption capacities (Joo et al., 2004), such that there is a potential for the transformation and removal of a range of inorganic and organic contaminants. Other studies have also indicated that $\mathrm{As}(\mathrm{III})$ is oxidized in parallel to the corrosion of $\mathrm{ZVI}$ at $\mathrm{pH} 7$ (Kanel et al., 2005; Leupin and Hug, 2005; Leupin et al., 2005; Lien and Wilkin, 2005; Sun et al., 2006), but mechanistic aspects have not been discussed in detail in these studies. The relevant surface and solution reactions in systems with ZVI are complex and highly dependent on $\mathrm{pH}$ and other water components. One important factor is the rate of generation of Fenton reagents [ $\mathrm{Fe}(\mathrm{II})$ and $\mathrm{H}_{2} \mathrm{O}_{2}$ ], which react to highly oxidizing $\cdot \mathrm{OH}$-radicals at low $\mathrm{pH}$ and 
apparently to less oxidizing intermediates above pH 5 (Hug and Leupin, 2003; Keenan and Sedlak, 2008).

Recently, Katsoyiannis et al. (2008a,b) studied kinetics and mechanism of Fenton reagent generation and As(III) oxidation and removal by ZVI in the $\mathrm{pH}$ range $3-11$ in aerated water. Experimental and kinetic data suggest that As(III) is oxidized mainly in solution by the Fenton reaction and removed by sorption on newly formed hydrous ferric oxides. It was further stated that $\mathrm{OH}$ radials are the main oxidant for $\mathrm{As}(\mathrm{III})$ at low $\mathrm{pH}$, whereas a more selective oxidant oxidizes As(III) at circumneutral $\mathrm{pH}$.

Hussm and Munir (2007) have developed a simple and effective arsenic filter based on composite iron matrix (zero valent iron) and won the prestigious Grainger gold medal award for their work. The development of this innovative filter (SONO filter) has been considered as one of the best treatment options for over 30 million people in Bangladesh who are still exposed to high arsenic concentrations. The filter has been approved by the Bangladesh Government and about 30,000 SONO filters were deployed all over Bangladesh and continue to provide more than a billion liters of safe drinking water. The filter removes arsenic species primarily by surface complexation reactions: $=\mathrm{FeOH}+\mathrm{H}_{2} \mathrm{AsO}_{4}^{-} \rightarrow=\mathrm{FeHAsO}_{4}^{-}+\mathrm{H}_{2} \mathrm{O}\left(\mathrm{K}=10^{24}\right)$ and $=\mathrm{FeOH}+\mathrm{HAsO}_{4}^{2-} \rightarrow=\mathrm{FeAsO}_{4}^{2-}+\mathrm{H}_{2} \mathrm{O}\left(K=10^{29}\right)$ on a specially manufactured composite iron matrix. The filter water meets WHO and Bangladesh standards, has no breakthrough, work without any chemical treatment (pre- or post-), without regeneration and without producing toxic wastes. It costs about $\$ 40 / 5$ years and produce $20-30 \mathrm{~L} / \mathrm{h}$ for daily drinking and cooking need of $1-2$ families. The spent material is completely non toxic-solid self contained iron-arsenate cement that does not leach in rainwater (Hussm and Munir, 2007).

Cornejo et al. (2008) has presented an in situ arsenic removal method applicable to highly contaminated water based on zerovalent iron (steel wool), lemon juice and solar radiation. Response surface method analysis was used to optimize the amount of zerovalent iron and the citrate concentration (lemon juice) to be used. The optimal conditions when using solar radiation to remove arsenic from natural water are: $1.3 \mathrm{~g} \mathrm{~L}^{-1}$ of steel wool and one drop (ca. $0.04 \mathrm{~mL}$ ) of lemon juice. Under these conditions, removal percentages are higher than $99.5 \%$ and the final arsenic concentration is below $10 \mu \mathrm{g} \mathrm{L}^{-1}$. The authors reported that the method is highly effective in removing arsenic and easy to use and inexpensive to implement.

BUET has constructed and tested iron coated sand based small scale units for the removal of arsenic from ground water. Iron coated sand has been prepared following a procedure similar to that adopted by Joshi and Chaudhuri (1996). The iron content of the iron coated sand was found to be $25 \mathrm{mg} \mathrm{g}^{-1}$ of sand. Raw water having $300 \mu \mathrm{g} \mathrm{L}^{-1}$ of arsenic when filtered through iron coated sand becomes essentially arsenic-free. It was found that 350 bed volumes could be treated satisfying the Bangladesh drinking water standard of $50 \mu \mathrm{g} \mathrm{L}^{-1}$. The saturated medium is regenerated by passing $0.2 \mathrm{~N}$ sodium hydroxide through the column or soaking the sand in $0.2 \mathrm{~N}$ sodium hydroxide followed by washing with distilled water. No significant change in bed volume in arsenic removal was found after 5 regeneration cycles. It was interesting to note that iron coated sand is equally effective in removing both $\mathrm{As}(\mathrm{III})$ and $\operatorname{As}(\mathrm{V})$.

Ko et al. (2007) have used colloidal iron oxide coated sand based treatment unit for arsenic removal. Modified porous media was made by the deposition of colloidal iron oxide onto sand grains at intermediate $\mathrm{pH}$ and ionic strength. $\mathrm{Kd}$ values from column experiments were $0.016-0.37 \mathrm{~L} \mathrm{~kg} \mathrm{~kg}^{-1}$ for $\mathrm{As}(\mathrm{III})$ and 0.023-0.85 $\mathrm{L} \mathrm{kg}^{-1}$ for $\mathrm{As}(\mathrm{V})$, being lower than those of batch experiments $\left(0.50\right.$ and $1.30 \mathrm{~L} \mathrm{~kg}^{-1}$ for $\mathrm{As}(\mathrm{III})$ and $\mathrm{As}(\mathrm{V})$, respectively) due to lower availability of surface adsorption sites in the packed column. Media-independent $\mathrm{Kd}$ values reflect the enhancement of arsenic adsorption with an increase of colloidal iron oxide coated sand fraction, apparently due to adsorption equilibration during arsenic transport under the same flow column conditions. The heterogeneous composition of two ground water samples also reduced arsenic adsorption. Therefore, arsenic elution near the initial breakthrough was regulated by available adsorption surface in a porous coated sand media as well as the effects of competing oxyanions. The exhaustion of adsorption capacity near the critical contamination level is sensitive to geochemical and remedial properties of the contaminants.

Sylvester et al. (2007) examined the removal efficiency of a hybrid sorbent utilizing nanoparticles of hydrous iron oxide for the removal of arsenic while Chen et al. (2007) have used ironimpregnated activated carbons for the removal of arsenic and have found the material very effective in arsenic removal. Oxyanionic arsenic species such as $\mathrm{As}(\mathrm{V})$ and $\mathrm{As}(\mathrm{III})$ adsorb at the iron oxyhydroxide surface by forming complexes with the surface sites. The goal was to load as much iron within the carbon pores as possible while also rendering as much of the iron to be available for sorbing arsenic. Surface oxidation of carbon by $\mathrm{HNO}_{3} / \mathrm{H}_{2} \mathrm{SO}_{4}$ or by $\mathrm{HNO}_{3} / \mathrm{KMnO}_{4}$ increased the amount of iron that could be loaded to 7.6-8.0\%; arsenic stayed below $10 \mathrm{ppb}$ until 12,000 bed volumes during rapid small-scale tests (RSSCTs) using Rutland, MA ground water (40-60 ppb arsenic, and pH of 7.6-8.0).

M/s Shin Nihon Salt Co. Ltd., Japan (2000) has developed and promoted Read-F Arsenic Removal Unit for arsenic removal in Bangladesh. Read-F displays high selectivity for arsenic ions under a broad range of conditions and effectively adsorbs both $\mathrm{As}(\mathrm{III})$ and $\mathrm{As}(\mathrm{V})$ without any pre-treatment. The Read-F is Ethylene-vinyl alcohol copolymer (EVOH)-borne hydrous cerium oxide in which hydrous cerium oxide $\left(\mathrm{CeO}_{2} \cdot n \mathrm{H}_{2} \mathrm{O}\right)$ is the adsorbent. The material contains no organic solvent or other volatile substance and is not classified as hazardous material. Laboratory test at BUET and field testing of the materials at four sites under the supervision of BAMWSP showed that the adsorbent is highly efficient in removing arsenic from ground water.

Pokhrel and Viraraghavan (2008) have used iron oxide-coated Aspergillus niger biomass for the removal of arsenic and reported reversible reactions between the arsenic species and the iron oxide-coated $A$. niger biomass. The thermodynamic study showed the spontaneous nature of the sorption of arsenic on the biomass. The high value of the heat of adsorption indicated that the mechanism of arsenic sorption was chemisorption. Martin et al. (2007) have described the synthesis of the iron(III) salt of a commercially available immobilized ligand, IMLIG, Octolig-21 and its use to remove arsenic from aqueous solutions. The synthesis was accomplished by treating an aqueous suspension of Octolig-21 with an equal weight of ferrous sulfate heptahydrate under nitrogen. The ferrous salt was then collected by sieving and allowed to oxidize to the iron(III) salt by exposure to air, and treatment with dilute sodium hydroxide converted the composite to the hydroxide. Using standard test water containing $300 \mathrm{ppb}$ As and column chromatography, reduction of the arsenic concentration to $3 \mathrm{ppb}$ or less in the effluent was achieved, using a pair of columns $(4.5 \mathrm{~cm}$ id; $1780 \mathrm{~mL}$ and $2019 \mathrm{~mL}$, respectively) in tandem. Subsequently, the $\mathrm{Fe}(\mathrm{III})-$ Octolig composite was tested for capacity, and it was calculated that with an input of $50 \mathrm{ppb}$ As, it could take up to a year for the effectiveness to be exhausted.

Recently, Mohan and Pittman (2007) reviewed various adsorption based technologies for the removal of arsenic from water and wastewater while Cundy et al. (2008) have reviewed iron based technologies for the removal of arsenic from ground water. 


\subsubsection{Indigenous filters and cartridges}

There are several filters available that use indigenous material as arsenic adsorbent. Red soil rich in oxidized iron, clay minerals, iron ore, iron scrap or fillings and processed cellulose materials are known to have capacity for arsenic adsorption. Some of the filters manufactured using these materials include Sono 3-Kolshi Filter, Granet Home-made Filter, Chari Filter, Adarsha Filter, Shafi Filter, and Bijoypur Clay/Processed Cellulose filters.

Milton et al. (2007) have examined the effectiveness of threepitcher filters used in Bangladesh. Data were collected at baseline and at 1,6 and 12 months after the intervention. The study demonstrates that arsenic removal technologies such as threepitcher filters are an effective option as a short-term measure. However, the three-pitcher filters that are not adequately maintained are not an effective option for long duration. The filter may be even harmful in the long term if the resultant water quality is not properly monitored.

The Garnet home-made filter contains relatively inert materials like brick chips and sand as filtering media. No chemical is added to the system. Air oxidation and adsorption on iron-rich brick chips and flocs of naturally present iron in ground water could be the reason for arsenic removal from ground water. The unit produced inadequate quantity of water and did not show reliable results in different areas of Bangladesh and under different operating conditions. The Chari filter also uses brick chips and inert aggregates in different Charis as filter media. The effectiveness of this filter in arsenic removal is not known.

The Shafi and Adarshs filters use clay material as filter media in the form of candle. The Shafi filter was reported to have good arsenic removal capacity but suffered from clogging of filter media. The Adarsha filter participated in the rapid assessment program but failed to meet the technical criterion of reducing arsenic to acceptable level (BAMWSP, DFID and Water Aid, 2000). Bijoypur clay and treated cellulose were also found to adsorb arsenic from water (Khair, 2000).

Filter units with cartridges filled with sorptive media or ionexchange resins are readily available in the market. These units remove arsenic like any other dissolved ions present in water but are not suitable for water having high impurities and iron content in water. Presence of ions having higher affinity than arsenic can quickly saturate the media requiring regeneration or replacement. Two household filters tested at BUET laboratories include Chiyoda Arsenic Removal Unit, Japan, and Coolmart Water Purifier, Korea.

The Chiyoda Arsenic Removal Unit could treat 800 BV meeting the WHO guideline value of $10 \mu \mathrm{g} \mathrm{L}^{-1}$ and $1300 \mathrm{BV}$ meeting the Bangladesh Standard of $50 \mu \mathrm{g} / \mathrm{L}$ when the feed water arsenic concentration was $300 \mu \mathrm{g} \mathrm{L}^{-1}$. The Coolmart Water Purifier could treat only $20 \mathrm{~L}$ of water with an effluent arsenic content of $25 \mu \mathrm{g} \mathrm{L}^{-1}$ (Ahmed et al., 2000). The initial and operation costs of these units are high and beyond the reach of the rural people.

\subsubsection{Other Miscellaneous Adsorbents}

During recent years, a wide variety of adsorbent systems have been developed for removal of arsenic. Hlavay and Polya'k (2005) prepared and characterized iron hydroxide-coated alumina for the removal of arsenic from drinking water. Andreas et al. (1998) studied the removal of arsenic by adsorption on granulated $\mathrm{Fe}(\mathrm{OH})_{3}$ on a pilot-plant scale and reported a specific load of $1.4 \mathrm{mg} \mathrm{g}^{-1}$. Manganese greensand (Subramanian et al., 1997) and iron oxide-coated sand and ferrihydrite (Thirunavukkarasu et al., 2001) were used for the removal of arsenic from drinking water. Activated carbon (Huang and Fu, 1984), fly ash (Diamadopoulos et al., 1993), modified fly ash (Goswami and Das, 2000), aluminum-loaded coral limestone (Ohki et al., 1996), nanoparticles of hydrous iron oxide (Sylvester et al., 2007), chitosan (Chen and
Chung, 2006), chitosan derivatives (Laurent et al., 2002), modified fungal biomass (Pokhrel and Viraraghavan, 2006), iron oxide minerals (Suvasis and Janet, 2003), activated neutralized red mud (Hulya et al., 2004), iron containing mesoporous carbon (Zhimang and Baolin, 2007), natural hematite, magnetite, and goethite (Javier et al., 2007), and iron oxide-impregnated activated carbon (Ronald et al., 2007) were used as adsorbents for the removal of arsenic from aqueous environments.

During the past two decades, biosorption has also received much attention due to the diversity of the available sorbent materials, such as fungal or bacterial biomass and alginate or chitosan biopolymers. Chitosan, an alkaline deacetylated product of chitin, has been used extensively due to its high hydrophilicity, presence of a large number of hydroxyl and amino groups with high activity as adsorption sites, nontoxicity, abundance in nature, biocompatibility and biodegradability. It is characterized by low porosity, which results in kinetic restrictions, thereby reducing sorption capacity. In its natural form, chitosan is soft and has a tendency to agglomerate and form gels. The specific binding sites of this sorbent are often not readily available for sorption. In addition, chitosan has a pKa of about 6.2 and is partially soluble in dilute mineral acids such as $\mathrm{HNO}_{3}, \mathrm{HCl}$ and $\mathrm{H}_{3} \mathrm{PO}_{4}$ (Boddu et al., 2008).

These characteristics pose a problem in wastewater treatment processes when chitosan is used for the removal of metal ions from acidic media. In order to improve chemical and mechanical resistance and to increase the sorption capacity of chitosan, it was subjected to physical (Piron et al., 1997) and chemical (Guibal et al., 1995) modifications. To increase stability under experimental conditions, chitosan was subjected to cross-linking with gluteraldehyde (Hsien and Rorrer, 1997). Kawamura et al. (1993) fabricated a highly porous chelating resin from chitosan and evaluated its adsorption capacity for $\mathrm{As}(\mathrm{III})$ along with other metal ions. Guibal et al. (1999) studied the influence of polymer structural parameters and experimental conditions on the adsorption of $\mathrm{As}(\mathrm{V})$ on modified chitosan beads. Dambies et al. (2000) investigated the adsorption characteristics of $\mathrm{As}(\mathrm{V})$ on molybdate-impregnated chitosan beads and reported that the sorbent could be reused after regenerating with phosphoric acid solution. The mechanism involved in the removal of arsenic through adsorption is an ionexchange precipitation between the impregnated metal and $\mathrm{As}(\mathrm{V})$ ions. In most cases desorption of $\mathrm{As}(\mathrm{V})$ from an aqueous medium is rather difficult and the adsorbent cannot be reused.

Recently, Boddu et al. (2008) have developed a novel composite chitosan bioadsorbent (CCB) for the removal of As(III) and As(V) from aqueous solutions by coating natural biopolymer, chitosan, on ceramic alumina, using a dip-coating process. The equilibrium adsorption data was analyzed using Langmuir, Freundlich and Redlich-Peterson adsorption models. All the three models represented the experimental data well. The monolayer adsorption capacity of the sorbent, as obtained from the Langmuir isotherm, is 56.50 and $96.46 \mathrm{mg} \mathrm{g}^{-1}$ of chitosan for $\mathrm{As}(\mathrm{III})$ and $\mathrm{As}(\mathrm{V})$, respectively. The difference in adsorption capacity for $\mathrm{As}(\mathrm{III})$ and $\mathrm{As}(\mathrm{V})$ was explained on the basis of speciation of arsenic at $\mathrm{pH}$ 4.0. Column adsorption results indicated that no arsenic was found in the effluent solution up to about 40 and 120 bed volumes of As(III) and $\mathrm{As}(\mathrm{V})$, respectively. Sodium hydroxide solution $(0.1 \mathrm{M})$ was found to be capable of regenerating the column bed.

\subsection{Ion exchange}

Ion exchange is a physical-chemical process in which ions are swapped between a solution phase and solid resin phase. The solid resin is typically an elastic three-dimensional hydrocarbon network containing a large number of ionizable groups electrostatically 
bound to the resin. These groups are exchanged for ions of similar charge in solution that have a stronger exchange affinity (i.e., selectivity) for the resin. In drinking water treatment, this technology is commonly used for softening and nitrate removal. The technology typically can reduce arsenic concentrations to less than $50 \mu \mathrm{g} \mathrm{L}^{-1}$ and in some cases to below $10 \mu \mathrm{g} \mathrm{L}^{-1}$. Its effectiveness is sensitive to a variety of untreated water contaminants and characteristics. It is used less frequently than precipitation/co-precipitation technology.

Arsenic removal is accomplished by continuously passing water under pressure through one or more columns packed with exchange resin. Fig. 4 shows a typical process flow diagram for ion exchange. As $(\mathrm{V})$ can be removed through the use of strong-base anion exchange resin in either chloride or hydroxide form. These resins are insensitive to $\mathrm{pH}$ in the range 6.5-9.0 (EPA, 2000a,b).

Different categories of synthetic resins can be used for arsenic removal. The process is similar to that of adsorption; just the medium is a synthetic resin of more well defined ion exchange capacity. Few manufacturers have developed synthetic resins suitable for arsenic removal. However, the resins need to be replenished after use and renewal interval is dependent on the quantity of arsenic in water. The hand pump attached arsenic removal plants working with ion exchange principle need meticulous attention for operation as well as for regular backwashing.

The efficiency of ion exchange process is radically improved by pre-oxidation of $\mathrm{As}(\mathrm{III})$ to $\mathrm{As}(\mathrm{V})$ but the excess of oxidant often needs to be removed before the ion exchange in order to avoid the damage of sensitive resins. The exchange affinity of various ions is a function of the net surface charge. Therefore, the efficiency of the ion exchange process for $\mathrm{As}(\mathrm{V})$ removal depends strongly on the solution $\mathrm{pH}$ and the concentration of other anions, most notably sulfates and nitrates. High levels of total dissolved solids (TDS) can also adversely affect the performance of an Ion Exchange system. In general, the Ion Exchange process is not an economically viable treatment technology if source water contains over $500 \mathrm{mg} \mathrm{L}^{-1}$ of TDS (Wang et al., 2000) or over $50 \mathrm{mg} \mathrm{L}^{-1}$ of sulfate. The presence of suspended solids in the feed water could gradually plug the media, thereby increasing headloss and necessitating more frequent backwashing. Therefore, pre-filtration is recommended if the source water turbidity exceeds 0.3 NTU. Development of ion specific resin for exclusive removal of arsenic can make the process very attractive.

Tetrahedron ion exchange resin filter tested under rapid assessment program in Bangladesh (BAMWSP, DFID and Water Aid, 2000) showed promising results in arsenic removal. The system needs pre-oxidation of As(III) by sodium hypochloride. The residual chlorine helps to minimize bacterial growth in the media. The saturated resin requires regeneration by recirculating sodium chloride $(\mathrm{NaCl})$ solution. The liquid wastes rich in salt and arsenic produced during regeneration require special treatment. Some other ion exchange resins have also been tried in Bangladesh but sufficient field test results are not available on the performance of those resins.

\subsection{Membrane technology}

Membrane technology can remove a wide range of contaminants from water. This technology typically can reduce arsenic concentrations to less than $50 \mu \mathrm{g} \mathrm{L}^{-1}$ and in some cases to below $10 \mu \mathrm{g} \mathrm{L}^{-1}$. However, its effectiveness is sensitive to a variety of untreated water contaminants and characteristics. It also produces a larger volume of residuals and tends to be more expensive than other arsenic treatment technologies. Therefore, it is used less frequently than precipitation/co-precipitation, adsorption and ion exchange.

There are four types of membrane processes: microfiltration (MF), ultrafiltration (UF), nanofiltration (NF) and reverse osmosis (RO). All the four processes are pressure-driven and are categorized by the size of the particles that can pass through the membranes or by the molecular weight cut off (i.e., pore size) of the membrane (EPA, 2000a,b). The force required to drive fluid across the membrane depends on the pore size; NF and RO require a relatively high pressure (50-150 psi), while MF and UF require lower pressure (5-100 psi). The low-pressure processes primarily remove contaminants through physical sieving and the high pressure processes through chemical diffusion across the permeable membrane (EPA, 2000a,b). Because arsenic species dissolved in water tend to have relatively low molecular weights, only NF and RO membrane processes are likely to effectively treat dissolved arsenic (EPA, 2000a,b).

Reverse osmosis and nanofiltration primarily remove arsenic by size exclusion. Subjected to a pressure gradient, a semi-permeable membrane allows water to pass through while retaining certain ions. RO membranes are more selective then NF membranes but require higher driving pressures (hence higher energy costs). Arsenic rejection in $\mathrm{RO}$ and $\mathrm{NF}$ is relatively insensitive to $\mathrm{pH}$ except that $\mathrm{As}(\mathrm{III})$ is rejected more completely at $\mathrm{pH}>8$ (Narasimhan et al., 2005) because it is anionic at high $\mathrm{pH}$, but uncharged at lower $\mathrm{pH}$. Both $\mathrm{NF}$ and $\mathrm{RO}$ are relatively expensive, generate a waste brine and consume large amounts of water.

Reverse Osmosis (RO) units can be used as stand-alone arsenic treatment under most water quality conditions and is capable of achieving over 97\% removal of $\mathrm{As}(\mathrm{V})$ and $92 \%$ removal of $\mathrm{As}(\mathrm{III})$ in a single pass (NSF, 2001a,b). Fig. 5 shows a flow diagram for a typical RO membrane process. Dashed lines indicate optional streams and processes. As an added benefit, RO also effectively removes several other constituents from water including organic carbon, salts, dissolved minerals and color. The treatment process is relatively insensitive to $\mathrm{pH}$. In order to drive water across the membrane surface against natural osmotic pressure, feed water must be sufficiently pressurized with a booster pump. For drinking water treatment, typical operating pressures are between 100 and 350 psi. Water recovery is typically $60-80 \%$, depending on the desired purity of the treated water.

$\mathrm{M} / \mathrm{s}$ Jago Corporation Limited promoted a household reverse osmosis water dispenser MRT-1000 manufactured by B \& T Science Co. Limited, Taiwan. This system was tested at BUET and showed

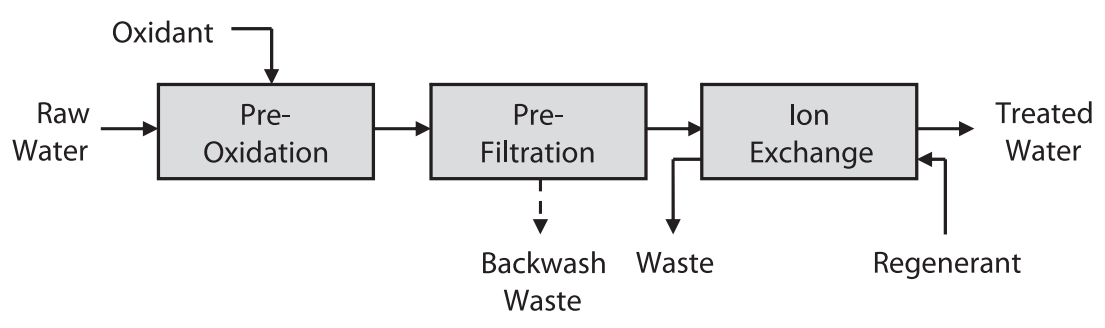

Fig. 4. Flow Diagram for Ion Exchange Process. 


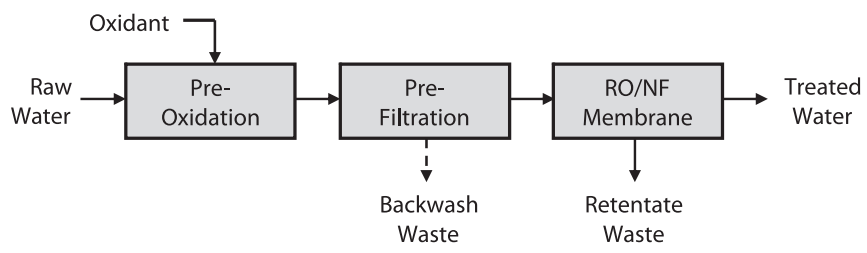

Fig. 5. Flow Diagram for RO Membrane Process.

As(III) removal efficiency more than $80 \%$. A wider spectrum reverse osmosis system developed by M/s Reid System Limited was also promoted in Bangladesh. Experimental results showed that the system could effectively reduce arsenic content along with other impurities in water. However, the capital and operational costs of the reverse osmosis system is relatively high.

Oh et al. (2000) applied reverse osmosis and nanofiltration membrane processes for the treatment of arsenic contaminated water applying low pressure by bicycle pump. A nanofiltration membrane process coupled with a bicycle pump could be operated under condition of low recovery and low-pressure range from 0.2 to $0.7 \mathrm{MPa}$. As(III) was found to have lower rejection than $\mathrm{As}(\mathrm{V})$ in ionized forms and hence water containing higher As(III) requires pre-oxidation for reduction of total arsenic acceptable level. In tube well water in Bangladesh the average ratio of $\mathrm{As}(\mathrm{III})$ to total arsenic was found to be 0.25 . However, the reverse osmosis process coupled with a bicycle pump system operating at $4 \mathrm{Mpa}$ can be used for arsenic removal because of its high $\mathrm{As}(\mathrm{III})$ rejection. The study concluded that low-pressure nanofiltration with pre-oxidation or reverse osmosis with a bicycle pump device could be used for the treatment of arsenic contaminated ground water in rural areas (Oh et al., 2000; Rahman and Rahaman, 2000).

Xia et al. (2007) have also investigated removal efficiency of arsenic from synthetic waters by nanofiltration (NF) membranes in China. Arsenic rejection experiments included variation of arsenic feed concentration, $\mathrm{pH}$ and existence of other ionic compounds. The possible influence of natural organic matter on $\mathrm{As}(\mathrm{V})$ rejection by nanofiltration membranes was also explored. The study shows the nanofiltration point-of-use (POU) systems were particularly suitable to treat arsenic-rich ground water in suburban China.

\section{Discussion}

Various technologies available for removal of arsenic from contaminated water are based mainly on six principles (oxidation/ filtration, biological oxidation, co-precipitation, adsorption, ion exchange and membrane technology) with their own merits and demerits. Typical treatment efficiencies and water losses for processes operated under normal conditions are provided in Table 2.

Oxidation/filtration normally refers to processes that are designed to remove naturally occurring iron and manganese from water. The processes involve the oxidation of the soluble forms of iron and manganese to their insoluble forms and then removal by filtration. If arsenic is present in the water, it can be removed via two primary mechanisms: adsorption and co-precipitation. The biological oxidation of iron and manganese as a treatment method for arsenic removal is a relatively new method. The process is based upon the fact that ground waters contaminated with arsenic are usually reducing and containing concentrations of iron and manganese. The filters for the removal of iron and manganese operating with pre aeration eventually are populated with iron and manganese oxidizing bacteria, which can oxidize very efficiently
Table 2

Typical Treatment Efficiencies and Water Loss.

\begin{tabular}{lll}
\hline Treatment Process & As(V) Removal Efficiency & Water Loss \\
\hline $\begin{array}{l}\text { Oxidation and Filtration } \\
\text { Greensand }\end{array}$ & $50-90 \% \mathrm{a}$ & $\leq 2 \%$ \\
$\begin{array}{l}\text { Biological Oxidation } \\
\text { Co-precipitation }\end{array}$ & $>95 \%$ & - \\
Enhanced Lime Softening & $90 \%$ & $1-2 \%$ \\
Enhanced Coagulation/Filtration & $<90 \%$ & $1-2 \%$ \\
$\quad$ With Alum & $95 \%$ & $1-2 \%$ \\
$\quad$ With Ferric Chloride & $90 \%$ & $5 \%$ \\
Coagulation Assisted Microfiltration & & $1-2 \%$ \\
$\begin{array}{l}\text { Adsorption } \\
\text { Activated Alumina }\end{array}$ & $95 \%$ & $1-2 \%$ \\
Iron Based Sorbents & $\mathrm{Up}$ to $98 \%$ & $1-2 \%$ \\
$\begin{array}{l}\text { Ion Exchange } \\
\text { Membrane Technology }\end{array}$ & $95 \%$ & $15-50 \%$ \\
Reverse Osmosis & $>95 \%$ & \\
\hline
\end{tabular}

Source: Modified from EPA (2000a).

${ }^{a}$ Depends on arsenic and iron concentrations.

As(III), which then can be adsorbed on iron and manganese oxides and get removed from the water. Precipitation/co-precipitation uses chemicals to transform dissolved contaminants into an insoluble solid or form another insoluble solid onto which dissolved contaminants are adsorbed. The solid is then removed from the liquid phase by clarification or filtration. Adsorption technology concentrates solutes at the surface of a sorbent, thereby reducing their concentration in the bulk liquid phase. The adsorption media is usually packed into a column. As contaminated water is passed through the column, contaminants are adsorbed. Ion exchange technology exchanges ions held electrostatically on the surface of a solid with ions of similar charge in a solution. The ion exchange media is usually packed into a column. As contaminated water is passed through the column, contaminants are removed. Membrane filtration separates contaminants from water by passing it through a semi-permeable membrane. The membrane allows some constituents to pass, while blocking others.

Among the conventional technologies, precipitation/co-precipitation is the most frequently used technology to treat arseniccontaminated water. The effectiveness of this technology is less likely to be reduced by characteristics and contaminants other than arsenic, compared to other water treatment technologies. It is also capable of treating water characteristics or contaminants other than arsenic, such as hardness or heavy metals. Systems using this technology generally require skilled operators; therefore, precipitation/co-precipitation is more cost effective at a large scale where labor costs can be spread over a larger amount of treated water produced.

The effectiveness of adsorption and ion exchange for arsenic treatment is more likely than precipitation/co-precipitation to be affected by characteristics and contaminants other than arsenic. Small capacity systems using these technologies tend to have lower operating and maintenance costs, and require less operator expertise. Adsorption and ion exchange tend to be used more often when arsenic is the only contaminant to be treated, for relatively smaller systems. Membrane filtration is used less frequently because it tends to have higher costs and produce a larger volume of residuals than other arsenic treatment technologies.

The most common technique for the removal of arsenic from ground water is coagulation with ferric salts, followed by filtration. However, a problem with this technique is the safe separation of the ferric hydroxide precipitate, for example by filtration or sedimentation and filtration, and the handling of the large amount of contaminated sludge. Therefore, the technique is not suitable for small water facilities. Another technique, which is quite simpler but 
less effective, is adsorption on activated alumina in fixed bed reactors. The typical capacity of these fixed bed reactors is $3000-10,000$ bed volumes with respect to tolerable arsenic level of $10 \mu \mathrm{g} \mathrm{L}^{-1}$. The residual mass of spent adsorbent is in the range of $50-200 \mathrm{~g} \mathrm{~m}^{-3}$ treated water. This is nearly 10 -fold more than the amount of coagulant sludge in the coagulation with ferric salts.

Activated alumina has been used for more than two decades to adsorb $\mathrm{As}(\mathrm{V})$-containing waters. The adsorbent does not require regeneration due to its limited life cycle. The optimum $\mathrm{pH}$ for arsenic removal with activated alumina is around 6.0; thus raw water usually needs to be $\mathrm{pH}$ adjusted by adding mineral acids or $\mathrm{CO}_{2}$. Activated alumina is ineffective in As(III) adsorption. Dilute caustic soda can be used to rinse and regenerate activated alumina. This regeneration technique may cause problem because it significantly lessens capacity and, more importantly, produces an arsenic-rich liquid waste stream.

Adsorption on iron based sorbents (IBS) is an emerging treatment technique for arsenic removal. The studies conducted with IBS media have revealed that the affinity of this media for arsenic is strong under natural $\mathrm{pH}$ conditions, relative to AA. This feature allows IBS to treat much higher bed volumes without the need for $\mathrm{pH}$ adjustment. However, similar to AA, optimal IBS performance is obtained at lower $\mathrm{pH}$ values. A new removal technique based on IBS has been developed at Technical University, Berlin (Germany) using granular ferric hydroxide in fixed bed reactors. An activated ferric oxide or ferric hydroxide demonstrate a larger capacity for arsenic removal than activated carbon, as within the coagulation-filtration ferric salts show better removal compared to alum at equal dosage. Furthermore, a granulated ferric hydroxide should be easy to apply as is activated alumina in fixed bed reactors. The technique combine the advantages of the coagulation-filtration technique, efficiency and small residual mass, with the fixed bed adsorption on activated alumina, simple processing. The high adsorption capacity coupled with the fact that it does not produce contaminated sludge or require chemical dosing, gives it an edge over other arsenic removal technologies. The adsorption technique rely on a simple filtration process over granular adsorbents like activated alumina or granular iron oxides and ferric hydroxides. Chemical dosing is usually not necessary. These techniques do not produce backwash sludge, the actual residual is the arsenic loaded adsorbent.

As a simple filtration process over granular adsorbent media, the technique usually does not require chemical dosing or pH adjustment. The media lasts five to 20 times longer than activated aluminas, and is applied as a non-regenerative media. GEH Wasserchemie GmbH \& Co. KG of Germany manufactures and distributes granular ferric hydroxide $\left(\mathrm{GEH}^{\mathrm{R}}\right)$ media. The Siemens Company USFilters is the exclusive North American distributor of the adsorbent, marketing it under the trade name $\mathrm{GFH}^{\mathrm{TM}}$ media. A number of arsenic treatment plants are in operation in Germany, Japan, the United States and elsewhere within Europe. A large number of handpump plants are also operating in West Bengal (India).

Driehaus et al. (1998) reported that approximately 35,000 bed volumes of water containing $16-17 \mu \mathrm{g} \mathrm{L}^{-1}$ of $\mathrm{As}(\mathrm{V})$ were filtered by granular ferric hydroxide (GFH) before the effluent arsenic increased to $10 \mu \mathrm{g} \mathrm{L}^{-1}$. $\mathrm{Fe}(0)$ filings, AA, and GFH costs were about $\$ 0.20 / \mathrm{lb}, \$ 0.41 / \mathrm{lb}$, and $\$ 4.60 / \mathrm{lb}$, respectively. The results indicate that a cost-effective filtration system can be developed for the removal of arsenic using ZVI. Aeration or/and pH adjustment may be required for treatment of ground water with low DO content and high $\mathrm{pH}$.

Filters with ZVI that are currently in use in Bangladesh (SONO filters) contain a large excess of iron so that sufficient $\mathrm{Fe}(0)$ surfaces probably remain after the formation of scales to sustain long-term corrosion. Furthermore, columns with sand and iron operating for weeks to years will most likely be populated with
Fe(II)-, Mn(II)-, and As(III)-oxidizing microorganisms that support As(III) oxidation (Katsoyiannis et al., 2004, 2008a,b). The complex reactions in ZVI-filters that are used for months to years are a subject of ongoing studies. Further research should be directed at improving the efficiency and extending the reactive life of ZVIfilters.

Ion exchange or membrane processes are quite expensive in nature and they appear to be not relevant in the context of South East Asia. Biological processes where microorganisms are used for treating the arsenic contaminated water and or sludge hold a lot of promise and coupled with adsorption or coagulation technique they may produce a good alternative remediation technique in South East Asia. The method can find broader application in South East Asia because of its several advantages over other conventional physico-chemical treatment methods. Further, biological processes hold lots of promise in sludge disposal protocol, which is very important, and is an integral component of any arsenic treatment technology.

\section{Conclusion and recommendations}

A remarkable technological development in arsenic removal processes has taken place during last few years. One should also realize that arsenic mitigation strategy should be location specific. A method suitable for a specific area should not be generalized for the other affected regions due to i) geographical and geomorphological variations, and ii) different socio-economic and literacy conditions of people. All the technologies described in this paper have their own merits and demerits and should be refined to make them suitable and sustainable for a particular situation. The modifications should be based on the pilot-scale implementation of the technologies with the objectives to:

- Improve effectiveness in arsenic removal,

- Reduce the capital and operation cost of the system,

- Make the technology user friendly,

- Overcome maintenance problems, and

- Resolve sludge and arsenic concentrates management problems.

Arsenic removal technologies have to compete with other technologies in which cost appears to be a major determinant in the selection of a treatment option by the users. The rural people habituated in drinking tube well water may find arsenic removal from tube well water as a suitable option for water supply. In many arsenic affected areas, arsenic removal may be the only option in the absence of an alternative safe source of water supply.

Based on the above observations, it is strongly recommended that awareness amongst the people and their whole hearted participation is very much essential to achieve success at field level. The technologies found effective and safe for arsenic removal from contaminated water should be promoted for wider implementation in the acute arsenic problem areas to avoid ingestion of excessive arsenic through water. The arsenic removal technologies may improve further through adaptation in rural environment through people's participation.

\section{References}

Abrahamson, H.B., Rezvani, A.B., Brushmiller, J.G., 1994. Photochemical and spectroscopic studies of complexes of iron (III) with citric acid and other carboxylic acids. Inorg. Chim. Acta 226, 117-127.

Ahmad, S.A., Bandaranayake, D., Khan, A.W., Hadi, S.A., Uddin, G., Halim, M.A., 1997. Arsenic contamination in groundwater and arsenicosis in Bangladesh. Int. J. Environ. Res. 7, 271-276.

Ahmed, K.M., Bhattacharya, P., Hasan, M.A., Akhter, S.H., Alam, S.M.M., Bhuyian, M.A.H., Imam, M.B., Khan, A.A., Sracek, O., 2004. Arsenic enrichment in 
groundwater of the alluvial aquifers in Bangladesh: an overview. Appl. Geochem. 19, 181-200.

Ahmed, F., Jalil, M.A., Ali, M.A., Hossain, M.D., Badruzzaman, A.B.M., 2000. An overview of arsenic removal technologies in BUET. In: Ahmed, M.F. (Ed.) Bangladesh Environment-2000. Bangladesh Poribesh Andolon, pp. 177-188.

Alam, M.G.M., Allinson, G., Stagnatti, F., Tanaka, A., Westbrooke, M., 2002. Arsenic contamination in Bangladesh groundwater: a major environmental and social disaster. Int. J. Environ. Res. 12, 236-253.

Andreae, M.O., 1977. Determination of arsenic species in natural waters. Anal. Chem $49,820-823$

Andreas, H., Dieter, S., Wolfgang, D., Horst, O., 1998. Removal of arsenic from drinking water by adsorption. BBR Wasser. Rohrbau. 49, 18-21.

Bajpai, S., Chaudhuri, M., 1999. Removal of arsenic from groundwater by manganese dioxide coated sand. J. Environ. Eng. 125 (8), 782-784.

BAMWSP, DFID and Water Aid Bangladesh, 2001. Rapid Assessment of Household Level Arsenic Removal Technologies, Phase-I and Phase-II, Final Report. WS Atkins International Limited.

Bang, S., Korfiatis, G.P., Meng, X., 2005. Removal of arsenic from water by zerovalent iron. J. Hazard. Mater. 121, 61-67.

Battaglia-Brunet, F., Dictor, M.C., Garrido, F., Crouzet, C., Morin, D., Dekeyser, K. Clarens, M., Baranger, P., 2002. An arsenic(III)-oxidizing bacterial population: selection, characterization, and performance in reactors. J. Appl. Microbiol. 93, 656-667.

Berg, M., Tran, H.C., Nguyen, T.C., Schertenleib, R., Giger, W., 2001. Arsenic contamination of groundwater and drinking water in Vietnam: a human health threat. Environ. Sci. Technol. 35, 2621-2626.

Berman, E., 1980. Toxic Metals and Their Analysis. Heyden and Sons, London,

BGS and DPHE, 2001. Arsenic Contamination of Groundwater in Bangladesh (Four Volumes). British Geological Survey and Bangladesh Department of Public Health Engineering.

BGS, 2001. Arsenic Contamination of Groundwater in Bangladesh, BGS Technical Report C/00/19. British Geological Survey, Keyworth, UK.

Bhattacharya, D., Jumawan Jr., A.B., Grieves, R.B., 1979. Separation of toxic heavy metals by sulfide precipitation. Separ. Sci. Technol. 14, 441-452.

Bhattacharya, P., Chatterjee, D., Jacks, G., 1997. Occurrence of arsenic contaminated groundwater in alluvial aquifers from Delta Plains, Eastern India: options for safe drinking water supply. Int. J. Water Resour. Dev. 13, 79-92.

Bissen, M., Frimmel, F.H., 2003. Arsenic - a review - Part II: oxidation of arsenic and its removal in water treatment. Acta Hydrochim. Hydrobiol. 31, 97-107.

Boddu, V.M., Abburi, K., Talbott, J.L., Smith, E.D., Haasch, R., 2008. Removal of arsenic (III) and arsenic (V) from aqueous medium using chitosan-coated biosorbent. Water Res. 42, 633-642.

Bose, P., Sharma, A., 2002. Role of iron in controlling speciation and mobilization of arsenic in subsurface environment. Water Res. 36, 4916-4926.

Braman, R.S., Foreback, C.C., 1973. Methylated forms of arsenic in the environment. Science 182, 1247-1249.

Bull, R.J., Kopfler, F.C., 1991. Health Effects of Disinfectants and Disinfection By-products. American Water Works Association, Denver.

Buschmann, J., Berg, M., Stengel, C., Sampson, M.L., 2007. Arsenic and manganese contamination of drinking water resources in Cambodia: coincidence of risk areas with low relief topography. Environ. Sci. Technol. 41, 2146-2157.

Chakraborti, D., Rahman, M.M., Paul, K., Chowdhury, U.K., Sengupta, M.K., Lodh, D., Chanda, C.R., Saha, K.C., Mukherjee, S.C., 2002. Arsenic calamity in the Indian subcontinent: what lessons have been learned? Talanta 58, 3-22.

Chakraborti, D., Mukherjee, S.C., Pati, S., Sengupta, M.K., Rahman, M.M., Chowdhury, U.K., Lodh, D., Chanda, C.R., Chakraborti, A.K., Basu, G.K., 2003. Arsenic groundwater contamination in Middle Ganga Plain, Bihar, India: a future danger? Environ. Health Perspect. 111, 1194-1201.

Chakraborti, D., Sengupta, M.K., Rahman, M.M., Ahamed, S., Chowdhury, U.K., Hossain, M.A., Mukherjee, S.C., Pati, S., Saha, K.C., Dutta, R.N., Quamruzzaman, Q 2004. Groundwater arsenic contamination and its health effects in the Ganga-Meghna-Brahmaputra plain. J. Environ. Monit. 6, 74N-83N

Chatterjee, A., Das, D., Mandal, B.K., Chowdhury, T.R., Samanta, G., Chakraborty, D. 1995. Arsenic in groundwater in six districts of West Bengal, India: the bigges arsenic calamity in the world. Part 1 . Arsenic species in drinking water and urine of the affected people. The Analyst 120, 643-656.

Chen, C.C., Chung, Y.C., 2006. Arsenic removal using biopolymer chitosan sorbent J. Environ. Sci. Health A Tox. Hazard. Subst. Environ. Eng. 41, 645-658.

Chen, H.W., Frey, M.M., Clifford, D., McNeill, L.S., Edwards, M., 1999. Arsenic treatment considerations. J. Am. Water Works Assoc. 91 (3), 74-85.

Chen, W., Parette, R., Zou, J., Cannon, F.S., Dempsey, B.A., 2007. Arsenic removal by iron-modified activated carbon. Water Res. 41, 1851-1858.

Cheng, C.R., Liang, S., Wang, H.C., Beuhler, M.D., 1994. Enhanced coagulation for arsenic removal. J. Am. Water Works Assoc. 86 (9), 79-90.

Chowdhury, T.R., Mandal, B.K., Samanta, G., Basu, G.K. Chowdhury, P.P. Chanda, C.R., 1997. Arsenic in groundwater in six districts of West Bengal, India, the biggest arsenic calamity in the world: the status report up to August 1995. In: Abernathy, C.O., Calderon, R.L., Chappel, W.R. (Eds.), Arsenic: Exposure and Health Effects. Chapman \& Hall, London, pp. 91-111.

Chowdhury, U.K., Biswas, B.K., Chowdhury, T.R., Samanta, G., Mandal, B.K., Basu, G.C., Chanda, C.R., Lodh, D., Saha, K.C., Mukherjee, S.K., Roy, S., Kabir, S. Quamruzzaman, Q., Chakraborti, D., 2000a. Groundwater arsenic contamination in Bangladesh and West Bengal, India. Environ. Health Perspect. 108, 393-397.
Chowdhury, U.K., Biswas, B.K., Chowdhury, T.R., Mandal, B.K., Samanta, G., Basu, G.K., 2000b. Arsenic groundwater contamination and sufferings of people in West Bengal, India and Bangladesh. In: Roussel, A.M., Anderson, R.A., Favier, A.E. (Eds.), Trace Elements in Man and Animals. Plenum Press, New York, pp. 645-650.

Chwirka, J., Thomsom, B., Stomp, J., 2000. Removing arsenic from groundwater J. Am. Water Works Assoc. 92 (3), 79-88.

Cornejo, L., Lienqueo, H., Arenas, M., Acarapi, J., Contreras, D., Yanez, J., Mansilla, H.D., 2008. In field arsenic removal from natural water by zero-valent iron assisted by solar radiation. Environ. Poll. 156 (3), 827-831.

Cullen, W.R., Reimer, K.J., 1989. Arsenic speciation in the environment. Chem. Rev. 89, 713-764.

Cundy, A.B., Hopkinson, L., Whitby, R.L.D., 2008. Use of iron-based technologies in contaminated land and groundwater remediation: a review. Sci. Total Environ. 400, 42-51.

Czekalla, C., Mevius, W., Hanert, H., 1985. Quantitative removal of iron and manganese by microorganisms in rapid sand filters (in situ investigations). Water Supply 3, 111-123.

Dahi, E., Liang, Q., 1998. Arsenic Removal in Hand Pumps Connected Iron Removal Plants in Noakhali, Bangladesh, International Conference on Arsenic Pollution of Ground Water in Bangladesh: Causes, Effect and Remedies. Dhaka, 8-12 February, 1998.

Dambies, L., Guibal, E., Roze, A., 2000. Arsenic (V) sorption on molybdate impregnated chitosan beads. Colloids Surf. A 170, 19-31.

Das, D., Chatterjee, A., Samanta, G., Mandal, B.K., Chowdhury, T.R., Chowdhury, P.P., Chanda, C., Basu, G., Lodh, D., Nandi, S., Chakroborty, T., Mandal, S., Bhattacharya, S.M., Chakraborty, D., 1994. Arsenic in groundwater in six districts of West Bengal, India: the biggest arsenic calamity in the world. The Analyst $119,168 \mathrm{~N}-170 \mathrm{~N}$.

Das, D., Chatterjee, A., Mandal, B.K., Samanta, G., Chakroborty, D., Chanda, B., 1995. Arsenic in groundwater in six districts of West Bengal, India: the biggest arsenic calamity in the world. Part 2. Arsenic concentration in drinking water, hair, nails, urine, skin-scales and liver tissues (biopsy) of the affected people. The Analyst 120, 917-924.

Diamadopoulos, E., Ioanidis, S., Sakellaropoulos, G.P., 1993. Arsenic (V) removal from aqueous solutions by fly ash. Water Res. 27, 1773-1777.

Dodd, M.C., Duy Vu, N., Ammann, A., Le, V.C., Kissner, R., Pham, H.V., Cao, T.H. Berg, M., Gunten, U.V., 2006. Kinetics and mechanistic aspects of As(III) oxidation by aqueous chlorine, chloramines, and ozone: relevance to drinking water treatment. Environ. Sci. Technol. 40 (10), 3285-3292.

DPHE, 2001. DPHE-Danida Arsenic Mitigation Pilot Project, June 28, 2001. http:// phys4.harvard.edu/ wilson/2bucket.html

Driehaus, W., Seith, R., Jekel, M., 1995. Oxidation of As(III) with manganese oxides in water treatment. Water Res. 29 (1), 297-305.

Driehaus, W., Jekel, M., Hildebrandt, U., 1998. Granular ferric hydroxides - A new adsorbent for the removal of arsenic from natural water. J. Water SRT-Aqua 47 (1), 30-35.

Driehaus, W., 2002. Arsenic removal - experience with GEH ${ }^{\circledR}$ process in Germany Water Sci. Technol.: Water Supply 2 (2), 275-280.

Duker, A.A., Carranza, E.J.M., Hale, M., 2005. Arsenic geochemistry and health. Environ. Int. 31, 631-641.

Edwards, M., 1994. Chemistry of arsenic removal during coagulation and Fe-Mn oxidation. J. Am. Water Works Assoc. 86 (9), 64-78.

EPA, 2000a. Technologies and Costs for Removal of Arsenic from Drinking Water. U.S. EPA, EPA 815R00028, Prepared by Malcolm Pirnie, Inc under contract 68C60039 for EPA ORD, December 2000. http://www.epa.gov/safewater/ars/ treatments_and_costs.pdf.

EPA, 2000b. Regulations on the Disposal of Arsenic Residuals from Drinking Water Treatment Plants. Office of Research and Development, U.S. EPA, EPA/600/R-00/ 025. May 2000. http://www.epa.gov/ORD/WebPubs/residuals/index.htm.

EPA, 2001. Cost Analyses for Selected Groundwater Cleanup Projects: Pump and Treat Systems and Permeable Reactive Barriers. U.S. EPA, Office of Solid Waste and Emergency Response. EPA-542-R-00-013, February 2001.

EPA, 2003a. Arsenic Treatment Technology Evaluation Handbook for Small Systems. U.S. EPA 816-R-03-014, July 2003.

EPA, 2003b. Removal of Arsenic from Drinking Water. U.S. EPA/600/R-03/019, March 2003.

Farrell, J., Wang, J., O’Day, P., Conklin, M., 2001. Electrochemical and spectroscopic study of arsenate removal from water using zero-valent iron media. Environ. Sci. Technol. 35, 2026-2032.

Faust, B.C., Zepp, R.G., 1993. Photochemistry of aqueous iron(III)-polycarboxylate complexes: roles in the chemistry of atmospheric and surface water. Environ. Sci. Technol. 27, 2517-2522.

Fields, K., Chen, A., Wang, L., 2000a. Arsenic Removal from Drinking Water by Coagulation/Filtration and Lime Softening Plants, EPA/600/R-00/063. Prepared by Battelle under contract 68 C70008 for U.S. EPA ORD, June 2000

Fields, K., Chen, A., Wang, L., 2000b. Arsenic Removal from Drinking Water by Iron Removal Plants, EPA 600R00086. Prepared by Battelle under contract 68C70008 for U.S. EPA ORD, August 2000.

Frost, F., Frank, D., Pierson, K., Woodruff, L., Raasina, B., Davis, R., Davies, J., 1993. A seasonal study of arsenic in groundwater, Snohomish County, Washington, USA. Environ. Geochem. Health 15, 209-213.

Fytianos, K., Christoforidis, Ch, 2004. Nitrate arsenic and chloride pollution of drinking water in Northern Greece. Elaboration by applying GIS. Environ. Monit. Assess. 93, 55-67. 
Gallard, H., Gunten, U.V., 2002. Chlorination of natural organic matter: kinetics of chlorination and of THM formation. Water Res. 36, 65-74.

Gesamp, 1986. (IMO/FAO/UNESCO/WMO/WHO/IAEA/UN/UNEP Joint Group of Experts on the Scientific Aspects of Marine Pollution), Review of potentially harmful substances-arsenic, mercury and selenium, Rept. Stud, GESAMP 28.

Ghurye, G., Clifford, D., 2001. Laboratory Study on the Oxidation of As(III) to As(V). EPA 600R01021, Prepared under contract 8CR311-NAEX for EPA ORD, March 2001.

Goswami, D., Das, A.K., 2000. Removal of arsenic from drinking water using modified fly-ash bed. Int. J. Water 1, 61-70.

Guibal, E., Jansson-Charrier, M., Saecudo, I., Le Cloirec, P., 1995. Enhancement of metal ion sorption performances of chitosan: effect of the structure on the diffusion properties. Langmuir 11, 591-598.

Guibal, E., Dambies, L., Milot, C., Roussy, J., 1999. Influence of polymer structural parameters and experimental conditions on metal anion sorption by chitosan. Polym. Int. 48, 671-680.

Heikens, A., Panaullah, G.M., Meharg, A.A., 2007. Arsenic behaviour from groundwater and soil to crops: impacts on agriculture and food safety. Rev. Environ. Contam. Toxicol. 189, 43-87.

Heikens, A., 2006. Arsenic Contamination of Irrigation Water, Soil and Crops in Bangladesh: Risk Implications for Sustainable Agriculture and Food Safety in Asia. Food and Agricultural Organization of the United States, Regional Office for Asia and the Pacific, Bangkok.

Hering, J.G., Elimelesh, M., 1995. International Perspective on Arsenic in Groundwater: Problems and Treatment Strategies. In: Proc. American Water Works Association, Annual Conference, 18-22 pp.

Hering, J.G., Chen, P.Y., Wilkie, J.A., Elimelech, M., Liang, S., 1996. Arsenic removal by ferric chloride. J. Am. Water Works Assoc. 88 (4), 155-167.

Hering, J.G., Chen, P., Wilkie, J.A., Elimelech, M., 1997. Arsenic removal from drinking water during coagulation. ASCE J. Env. Eng. 123 (8), 800-807.

Hlavay, J., Polyák, K., 2005. Determination of surface properties of iron hydroxidecoated alumina adsorbent prepared for removal of arsenic from drinking water. J. Colloid Interface Sci. 284, 71-77.

Hsien, T.Y., Rorrer, G., 1997. Heterogeneous cross-linking of chitosan gel beads: kinetics, modeling and influence on cadmium ion adsorption capacity. Ind. Eng. Chem. Res. 36, 3631-3638.

Huang, C.P., Fu, P.L., 1984. Treatment of arsenic (V) containing water by activated carbon process. J. Water Pollut. Control Fed. 56, 233-242.

Hug, S.J., Leupin, O., 2003. Iron-catalyzed oxidation of arsenic(III) by oxygen and by hydrogen peroxide: $\mathrm{pH}$-dependent formation of oxidants in the Fenton reaction. Environ. Sci. Technol. 37 (12), 2734-2742.

Hug, S.J., Laubscher, H.-U., James, B.R., 1997. Iron(III) catalyzed photochemical reduction of chromium(VI) by oxalate and citrate in aqueous solutions. Environ. Sci. Technol. 31, 160-170.

Hug, S.J., Canonica, L., Wegelin, M., Gechter, D., Gunten, U.V., 2001. Solar oxidation and removal of arsenic at circumneutral $\mathrm{pH}$ in iron containing waters. Environ. Sci. Technol. 35 (10), 2114-2121.

Hulya, G.F., Jens, C.T., David, M., 2004. Adsorption of arsenic from water using activated neutralized red mud. Environ. Sci. Technol. 38, 2428-2434.

Hussam, A., Munir, A.K.M., 2007. A simple and effective arsenic filter based on composite iron matrix: development and deployment studies for groundwater of Bangladesh. J. Environ. Sci. Health, Part A 42 (12), 1869-1878.

Ike, M., Miyazaki, T., Yamamoto, N., Sei, K., Soda, S., 2008. Removal of arsenic from groundwater by arsenite-oxidizing bacteria. Wat. Sci. Technol. 58 (5), 1095-1100.

Jain, C.K., Ali, I., 2000. Arsenic: occurrence, toxicity and speciation techniques. Water Res. 34 (17), 4304-4312.

Javier, G., Maria, M., Joan de, P., Miquel, R., Lara, D., 2007. Arsenic sorption onto natural hematite, magnetite and goethite. J. Hazard. Mater. 141, 575-580.

Jekel, M., Seith, R., 2000. Comparison of conventional and new techniques for the removal of arsenic in a full scale water treatment plant. J. Water Supply 18 (1), 628-631.

Jekel, M.R., 1994. Removal of Arsenic in Drinking Water Treatment. In: Nriagu, J.O. (Ed.), Arsenic in the Environment, Part 1: Cycling and Characterization. John Wiley \& Sons, Inc., New York.

Joo, S.H., Feitz, A.J., Waite, T.D., 2004. Oxidative degradation of the carbothioate herbicide, molinate, using nanoscale zero-valent iron. Environ. Sci. Technol. 38, 2242-2247.

Joshi, A., Chaudhuri, M., 1996. Removal of arsenic from groundwater by iron-oxidecoated sand. ASCE J. Env. Eng. 122 (8), 769-771.

Kanel, S.R., Manning, B., Charlet, L., Choi, H., 2005. Removal of arsenic(III) from groundwater by nanoscale zero-valent iron. Environ. Sci. Technol. 39, 1291-1298.

Kartinen, E.O., Martin, C.J., 1995. An overview of arsenic removal processes. J. Desalination 103, 79-88.

Katsoyiannis, I.A., Katsoyiannis, A.A., 2006. Arsenic and other metal contamination of groundwaters in the industrial area of Thessaloniki, Northern Greece. Environ. Monit. Assess. 123, 393-406.

Katsoyiannis, I.A., Zouboulis, A.I., 2004a. Application of biological processes for the removal of arsenic from groundwaters. Water Res. 38 (1), 17-26.

Katsoyiannis, I.A., Zouboulis, A.I., 2004b. Biological treatment of $\mathrm{Mn}$ (II) and Fe(II) containing groundwater: kinetic considerations and product characterization. Water Res. 38 (7), 1922-1932.

Katsoyiannis, I.A., Zouboulis, A.I., 2006. Use of iron- and manganese-oxidizing bacteria for the combined removal of iron, manganese and arsenic from contaminated groundwater. Water Qual. Res. J. Can. 41, 117-129.

Katsoyiannis, I.A., Zouboulis, A.I., Althoff, H.W., Bartel, H., 2002. As(III) removal from groundwater using fixed bed upflow bioreactors. Chemosphere 47, 325-332.
Katsoyiannis, I.A., Zouboulis, A.I., Jekel, M., 2004. Kinetics of bacterial As(III) oxidation and subsequent $\mathrm{As}(\mathrm{V})$ removal by sorption onto biogenic manganese oxides during groundwater treatment. Ind. Eng. Chem. Res. 43, 486-493.

Katsoyiannis, I.A., Hug, S.J., Ammann, A., Zikoudi, A., Hatziliontos, C., 2007. Arsenic speciation and uranium concentrations in drinking water supply wells in Northern Greece: correlations with redox indicative parameters and implications for groundwater treatment. Sci. Total Environ. 383, 128-140.

Katsoyiannis, I.A., Ruttimann, T., Hug, S.J., 2008a. pH dependence of Fenton reagent generation and $\mathrm{As}(\mathrm{III})$ oxidation and removal by corrosion of zero valent iron in aerated water. Environ. Sci. Technol. 42, 7424-7430.

Katsoyiannis, I.A., Zikoudi, A., Hug, S.J., 2008b. Arsenic removal from groundwaters containing iron, ammonium, manganese and phosphate: a case study from a treatment unit in northern Greece. Desalination 224, 330-339.

Kawamura, Y., Mitsuhashi, M., Tanibe, H., Yoshida, H., 1993. Adsorption of metal ions on polyaminated highly porous chitosan chelating resin. Ind. Eng. Chem. Res. 32, 386-391.

Keenan, C.R., Sedlak, D.L., 2008. Factors affecting the yield of oxidants from the reaction of nanoparticulate zero-valent iron and oxygen. Environ. Sci. Technol. 42, 1262-1267.

Khair, A., 2000. Factors responsible for the presence of arsenic in groundwater: Bangladesh context. In: Ahmed, M.F. (Ed.), Bangladesh Environment-2000. Bangladesh Poribesh Andolon, pp. 198-209.

Kim, M.J., Nriagu, J.O., 2000. Oxidation of arsenite in ground water using ozone and oxygen. Sci. Total Environ. 247 (1), 71-79.

Kim, M.J., Nriagu, J.O., Haack, S., 2002. Arsenic species and chemistry in groundwater of southeast Michigan. Environ. Pollut. 120, 379-390.

Ko, I., Davis, A.P., Kim, J.Y., Kim, K.W., 2007. Arsenic removal by a colloidal iron oxide coated sand. J. Environ. Eng. 133 (9), 891-898.

Kohnhorst, A., Paul, P., 2000. Testing simple arsenic removal methods. In: Water, Sanitation and Hygiene: Challenges of the Millennium, Pre-prints of the 26 WEDC Conference, Dhaka, Bangladesh, pp. 177-181.

Lackovic, J.A., Nikolaidis, N.P., Dobbs, G.M., 2000. Inorganic arsenic removal by zerovalent iron. Environ. Eng. Sci. 17, 29-39.

Laurent, D., Thierry, V., Eric, G., 2002. Treatment of arsenic containing solutions using chitosan derivatives: uptake mechanism and sorption performances. Water Res. 36, 3699-3710.

Leupin, O.X., Hug, S.J., 2005. Oxidation and removal of arsenic (III) from aerated groundwater by filtration through sand and zerovalent iron. Water Res. 39, 1729-1740.

Leupin, O.X., Hug, S.J., Badruzzaman, A.B.M., 2005. Arsenic removal from Bangladesh tube well water with filter columns containing zero-valent iron filings and sand. Environ. Sci. Technol. 39, 8032-8037.

Lewis, R.J., Tatken, R.L., 1978. Registry of Toxic Effects of Chemical Substances. U.S Department of Health, Education and Welfare, Cincinnati, OH, USA.

Lien, H.L., Wilkin, R.T., 2005. High level arsenite removal from groundwater by zerovalent iron. Chemosphere 59, 377-386.

MacPhee, M.J., Charles, G.E., Cornwell, D.A., 2001. Treatment of Arsenic Residuals from Drinking Water Removal Processes. EPA 600R 01033, Prepared by Environmental Engineering \& Technology, Inc. under contract 8CR613-NTSA for EPA ORD, June 2001.

Madiec, H., Cepero, E., Mozziconacci, D., 2000. Treatment of arsenic by filter coagulation: a South American advanced technology. J. Water Supply 18 (1), 613-618.

Mandal, B.K., Suzuki, K.T., 2002. Arsenic around the world: a review. Talanta 58, 201-235.

Mandal, B.K., Chowdhury, T.R., Samanta, G., Basu, G.K., Chowdhury, P.P. Chanda, C.R., Lodh, D., Karan, N.K., Dhar, R.K., Tamili, D.K., Das, D., Saha, K.C., Chakraborti, D., 1996. Arsenic in groundwater in seven districts of West Bengal India - The biggest arsenic calamity in the world. Curr. Sci. 70 (11), 976-986.

Manning, B.A., Fendorf, S.E., Bostick, B., Suarez, D.L., 2002a. Arsenic(III) and arsenic(V) adsorption reactions on synthetic birnessite. Environ. Sci. Technol. 36, 976-981.

Manning, B.A., Hunt, M.L., Amrhein, C., Yarmoff, J.A., 2002b. Arsenic(III) and arsenic(V) reactions with zerovalent iron corrosion products. Environ. Sci. Technol. 36, 5455-5461.

Martin, D.F., Donnell, L.O., Martin, B.B., Alldredge, R., 2007. Removal of aqueous arsenic using iron attached to immobilized ligands (IMLIGs). J. Environ. Sci. Health, Part A 42, 97-102.

McArthur, J.M., Ravenscroft, P., Safiulla, S., Thirlwall, M.F., 2001. Arsenic in groundwater: testing pollution mechanisms for sedimentary aquifers in Bangladesh. Water Resour. Res. 37, 109-117.

McArthur, J.M., Banjeree, D.M., Hudson-Edwards, K.A., Mishra, R., Purohit, R., Ravenscroft, P., Cronin, A., Howarth, R.J., Chatterjee, A., Talukder, T., Lowry, D., Houghton, S., Chadha, D.K., 2004. Natural organic matter in sedimentary basins and its relation to arsenic in anoxic ground water: the example of West Bengal and its worldwide implications. Appl. Geochem. 19, 1255-1293.

Melitas, N., Wang, J., Conklin, M., O'Day, P., Farrell, J., 2002. Understanding soluble arsenate removal kinetics of zerovalent iron media. Environ. Sci. Technol. 36, 2074-2081.

Meng, X.G., Bang, S., Korfiatis, G.P., 2000. Effects of silicate, sulphate and carbonate on arsenic removal by ferric chloride. Water Res. 34, 1255-1261.

Milton, A.H., Smith, W., Dear, K., Ng, J., Sim, M., Ranmuthugala, G., Lokuge, K., Caldwell, B., Rahman, A., Rahman, H., Shraim, A., Huang, D., Shahidullah, S.M., 2007. A Randomised intervention trial to assess two arsenic mitigation options in Bangladesh. J. Environ. Sci. Health, Part A 42 (12), 1897-1908.

Mohan, D., Pittman Jr., C.U., 2007. Arsenic removal from water/wastewater using adsorbents-a critical review. J. Hazard. Mater. 142, 1-53. 
Molnar, L., Vircikova, E., Lech, P., 1994. Experimental study of As(III) oxidation by hydrogen peroxide. Hydrometallurgy 35, 1-9.

Moncure, G., Jankowski, P.A., Drever, J.I., 1992. The hydrochemistry of arsenic in reservoir sediments, Miltown, Montana, USA. In: Kharaka, Y.K., Maest, A.S (Eds.), Water Rock-Interaction. Low Temperature Environments, vol. 1. A.A Balkema, Rotterdam, pp. 513-516.

Moore, J.N., Walker, J.R., Hayes, T.H., 1990. Reaction scheme for the oxidation of As(III) by birnessite. Clays Clay Miner. 38 (5), 549-555.

Mouchet, P., 1992. From conventional to biological removal of iron and manganese in France. J. Am. Water Works Assoc. 84 (4), 158-166.

Mukherjee, A.B., Bhattacharya, P., 2001. Arsenic in groundwater in the Bengal Delta plain: slow poisoning in Bangladesh. Environ. Rev. 9, 189-220.

Mukherjee, A., Sengupta, M.K., Hossain, M.A., 2006. Arsenic contamination in groundwater: a global perspective with emphasis on the Asian scenario. J. Health Popul. Nutr. 24 (2), 142-163.

Murcott, S., 2000. A Comprehensive Review of Low-cost, Well-Water Treatment Technologies for Arsenic Removal. http://phys4.harvard.edu/ wilson,/ murcott2.html.

Narasimhan, R., Thomson, B., Chwirka, J., Lowry, J., 2005. Chemistry and Treatment of Arsenic in Drinking Water. American Water Works Association Research Foundation.

National Research Council (NRC), 1999. Arsenic in Drinking Water. National Academy Press, Washington, D.C.

Nesbitt, H.W., Canning, G.W., Bancroft, G.M., 1998. XPS study of reductive dissolution of 7A birnessite by $\mathrm{H}_{3} \mathrm{AsO}_{3}$ with constraints on the reaction mechanism. Geochim. Cosmochim. Acta 62, 2097.

Ng, J.C., Wang, J., Shraim, A., 2003. A global health problem caused by arsenic from natural sources. Chemosphere 52, 1353-1359.

Nickson, R., McArthur, J.M., Burgess, W., Ahmed, M., Ravenscroft, P., Rahman, M. 1998. Arsenic poisoning of groundwater in Bangladesh. Nature 395, 338 .

Nickson, R.T., McArthur, J.M., Ravenscroft, P., Burgess, W.G., Ahmed, K.M., 2000. Mechanism of arsenic release to groundwater, Bangladesh and West Bengal. Appl. Geochem. 15, 403-413.

Nikolaidis, N.P., Dobbs, G.M., Lackovic, J.A., 2003. Arsenic removal by zero valent iron: field, laboratory and modelling studies. Water Res. 37, 1417-1425.

Nordstrom, D.K., 2002. World wide occurrences of arsenic in groundwater. Science 296, 143-145.

NSF International, 2001a. Environmental Technology Verification Report: Removal of Arsenic in Drinking Water - Hydranautics ESPA2-4040 Reverse Osmosis Membrane Element Module. NSF 0120EPADW395, March 2001.

NSF International, 2001b. Environmental Technology Verification Report: Removal of Arsenic in Drinking Water - KOCH Membrane Systems TFC - ULP4 Reverse Osmosis Membrane Module. NSF 0125EPADW395, August 2001.

Oh, J.I., Urase, T., Kitawaki, H., Rahman, M.M., Rhahaman, M.H., Yamamoto, K., 2000. Modelling of arsenic rejection considering affinity and steric hindrance effect in nonofiltration membranes. Water Sci. Technol. 42 (3-4), 173-180.

Ohki, A., Nakayachigo, K., Naka, K., Maeda, S., 1996. Adsorption of inorganic and organic arsenic compounds by aluminium loaded coral lime stone. Appl. Organometal. Chem. 10, 747-752.

Oscarson, D.W., Huang, P.M., Liaw, W.K., Hammer, U.T., 1983. Kinetics of oxidation of arsenite by various manganese dioxides. Soil Sci. Soc. Am. J. 47, 644

Penrose, W.R., 1974. Arsenic in the marine and aquatic environments. Analysis, occurrence and significance. CRC Crit. Rev. Environ. Contr. 4, 465-482.

Pettine, M., Campanella, L., Millero, F.J., 1999. Arsenite oxidation by $\mathrm{H}_{2} \mathrm{O}_{2}$ in aqueous solutions. Geochim. Cosmochim. Acta 63 (18), 2727-2735.

Pierce, M.L., Moore, C.B., 1982. Adsorption of arsenite and arsenate on amorphous iron hydroxide. Water Resour. 16, 1247-1253.

Piron, E., Accominoti, M., Domard, A. 1997. Interaction between chitosan and uranyl ions. Role of physical and physicochemical parameters on the kinetics of sorption. Langmuir 13, 1653-1658.

Pokhrel, D., Viraraghavan, T., 2006. Arsenic removal from aqueous solutions by a modified fungal biomass. Water Res. 40, 549-552.

Pokhrel, D., Viraraghavan, T., 2008. Arsenic removal from aqueous solution by iron oxide-coated biomass: common ion effects and thermodynamic analysis. Separ. Sci. Technol. 43 (13), 3545-3562.

Polya, D.A., Gault, A.G., Diebe, N., Feldman, P., Rosenboom, J.W., Gilligan, E., Fredericks, D., Milton, A.H., Sampson, M., Rowland, H.A.L., Lythgoe, P.R. Middleton, C., Cooke, D.A., 2005. Arsenic hazard in shallow Cambodian groundwaters. Mineral. Mag. 69, 807-823.

Pontius, F.W. (Ed.), 1990. Water Quality Treatment: A Handbook of Community Water Supplies, American Water Works Association. McGraw-Hill, New York.

Pontius, F.W., 1995. Crafting a new arsenic rule. J. Am. Water Works Assoc. 87 (9), 6-10.

Rahman, M.M., Rahaman, M.H., 2000. Application of low-pressure nanofiltration coupled with a bicycle pump for the treatment of arsenic-contaminated groundwater. Desalination 132, 307-314.

Rahman, M.M., Chowdhury, U.K., Mukherjee, S.C., Mondal, B.K., Paul, K., Lodh, D., 2001. Chronic arsenic toxicity in Bangladesh and West Bengal, India - a review and commentary. J. Toxicol. Clin. Toxicol. 39, 683-700.

Ramaswami, A., Tawachsupa, S., Isleyen, M., 2001. Batch mixed iron treatment of high arsenic waters. Water Res. 35, 4474-4479.

Ravenscroft, P., McArthur, J.M., Hoque, B.A., 2001. Geochemical and palaeohydrological controls on pollution of groundwater by arsenic. In: Chappel, W.R., Abernathy, C.O., Calderon, R. (Eds.), Arsenic Exposure and Health Effects IV. Elsevier Science Ltd., Oxford, pp. 53-78.
Robertson, F.N., 1986. Occurrence and solubility controls of trace elements in groundwater in alluvial basins of Arizona. In: I.W. Anderson and A.I. Johnson (Ed.) Regional Aquifer Systems of United States, Southwest Alluvial Basins of Arizona. American Water Resources Association Monograph, Series 7, pp. 69-80.

Robertson, F.N., 1989. Arsenic in ground water under oxidizing conditions, southwest United States. Environ. Geochem. Health 11, 171-176.

Ronald Jr., L.V., Brian, E.R., Edward, H.S., 2007. Modeling As(V) removal in iron oxide impregnated activated carbon columns. J. Env. Eng. 133, 121-124.

Rosenblum, E., Clifford, D., 1984. The Equilibrium Arsenic Capacity of Activated Alumina. EPA-600/52-83-107. U.S. EPA, Cincinnati, OH.

Ryu, J.H., Gao, S., Dahlgren, R.A., Zierenberg, R.A., 2002. Arsenic distribution speciation and solubility in shallow groundwater of Owen Dry lake California. Geochim. Cosmochim. Acta 66, 2904-2981.

Sancha, A.M., 2000. Removal of arsenic from drinking water supplies: Chile experience. Water Supply 18, 621-625.

Santini, J.M., Sly, L.I., Schnagl, R.D., Macy, J.M., 2000. A new chemolithotrophic arsenite-oxidizing bacterium isolated from a gold mine: phylogenetic, physiological and preliminary biochemical studies. Appl. Environ. Microbiol. 66, 92-97.

Sarkar, A., Thogersen, Choudhury, Rahaman, Akhter, Choudhury, 2000. Bucket treatment unit for arsenic removal. In: Water, Sanitation and Hygiene: Challenges of the Millennium, Pre-prints of the 26 WEDC Conference, Dhaka, Bangladesh, pp. 308-310.

Schlottmann, J.L., Breit, G.N., 1992. Mobilization of As in the Central Oklahoma Aquifer, USA. In: Kharaka, Y.K., Maest, A.S. (Eds.), Water-Rock Interaction. Low Temperature Environments, vol. 1. A. A. Balkema, Rotterdam, pp. 835-838.

Scott, M.J., Morgan, J.J., 1995. Reactions at oxide surfaces. 1. Oxidation of As(III) by synthetic birnessite. Environ. Sci. Technol. 29 (8), 1898-1905.

Seith, R., Jekel, M., 1997. Biooxidation of As(III) in fixed bed bioreactors. Vom Wasser 89, 283-296.

Selvin, N., Messham, G., Simms, J., Pearson, I., Hall, J., 2000. The Development of Granular Ferric Media - Arsenic Removal and Additional Uses in Water Treatment. In: Proc. AWWA Water Quality Technology Conference. Salt Lake City, USA.

Shaikh, A.U., Tallman, D.E., 1978. Species specific analysis of nano gram quantities of arsenic in natural water by arsine generation followed by graphite furnace atomic absorption spectrometry. Anal. Chim. Acta 98, 251-259.

Shen, Y.S., 1973. Study of arsenic removal from drinking water. J. Am. Water Works Assoc. 65 (8), 543-548.

Shin Nihon Salt Co. Ltd, 2000. Report on Performance of Read-F Arsenic Removal Unit (ARU), October 2000

Shrestha, R.R., Shrestha, M.P., Upadhyay, N.P., Pradhan, R., Khadka, R., Maskey, A., Maharjan, M., Tuladhar, S., Dahal, B.M., Shrestha, K., 2003. Groundwater arsenic contamination, its health impact and mitigation program in Nepal. J. Environ. Sci. Health A38, 185-200.

Singh, A.K., 2006. Chemistry of arsenic in groundwater of Ganges-Brahmaputra river basin. Curr. Sci. 91, 599-606.

Smedley, P.L., Kinniburgh, D.G., 2002. A review of the source, behaviour and distribution of arsenic in natural waters. Appl. Geochem. 17, 517-568.

Smedley, P.L., Zhang, M., Zhang, G., Luo, Z., 2003. Mobilisation of arsenic and other trace elements in fluviolacustrine aquifers of the Huhhot Basin, Inner Mongolia. Appl. Geochem. 18, 1453-1477.

Sorg, T.J., Logsdon, G.S., 1974. Treatment technology to meet the interim primary drinking water regulations for inorganics: part 2. J. Am. Water Works Assoc. 70 (7), 379-393.

Stranger, G., van Truong, T., Le Thi My Ngoc, K.S., Luyen, T.V., Thauh, T.T., 2005. Arsenic in groundwater of the lower Mekong. Environ. Geochem. Health 27, 341-357.

Stugeron, R.E., Siu, K.W.M., Willie, S.N., Berman, S.H., 1989. Quantification of arsenic species in a river water reference material for trace metals by graphite furnace atomic absorption spectrometry technique. Analyst 114, 1393-1396.

Su, C., Puls, R.W., 2001. Arsenate and arsenite removal by zerovalent iron: kinetics, redox transformation, and implications for in situ groundwater remediation. Environ. Sci. Technol. 35, 1487-1492.

Su, C., Puls, R.W., 2003. In situ remediation of arsenic in simulated groundwater using zerovalent iron: laboratory column tests on combined effects of phosphate and silicate. Environ. Sci. Technol. 37, 2582-2587.

Subramanian, K.S., Viraraghavan, T., Tanjore, S., 1997. Manganese greensand for removal of arsenic in drinking water. Water Qual. Res. J. Can. 32, 551-556.

Sun, H., Wang, L., Zhang, R., Sui, J., Xu, G., 2006. Treatment of groundwater polluted by arsenic compounds by zero valent iron. J. Hazard. Mater. 129, 297-303.

Sun, G., 2004. Arsenic contamination and arsenicosis in China. Toxicol. Appl. Pharmacol. 198, 268-271.

Suvasis, D., Janet, G.H., 2003. Comparison of arsenic (V) and arsenic (III) sorption on to iron oxide minerals: implications for arsenic mobility. Environ. Sci. Technol. 37, 4182-4189.

Sylvester, P., Westerhoff, P., Moller, T., Badruzzaman, M., Boyd, O., 2007. A hybrid sorbent utilizing nanoparticles of hydrous iron oxide for removal arsenic from drinking water. Environ. Eng. Sci. 24, 104-112.

Tandukar, N., Bhattacharya, P., Mukherjee, A.B., 2001. Preliminary assessment of arsenic contamination in groundwater in Nepal. In: Proceedings of the International Conference on Arsenic in the Asia-Pacific Region: Managing Arsenic for Our Future, 20-23 November 2001. CSIRO, Adelaide, Australia, Glen Osmond, South Australia, Land and Water, pp. 103-105.

Thirunavukkarasu, O.S., Viraraghavan, T., Subramanian, K.S., 2001. Removal of arsenic in drinking water by iron oxide coated sand and ferrihydrite - batch studies. Water Qual. Res. J. Can. 36, 55-70. 
Tournassat, C., Charlet, L., Bosbach, D., Manceau, A., 2002. Arsenic(III) oxidation by birnessite and precipitation of manganese(II) arsenate. Environ. Sci. Technol. 36, 493-500.

Viraraghavan, T., Subramanian, K.S., Tanjore, S., 1996. Removal of arsenic in drinking water by manganese greensand filtration, oxide-coated sand filtration and ion exchange treatment. Adv. Filtr. Sep. Technol. 10, 502-507.

Voegelin, A., Hug, S.J., 2003. Catalyzed oxidation of arsenic(III) by hydrogen peroxide on the surface of ferrihydrite: an in situ ATR-FTIR study. Environ. Sci. Technol. 37, 972-978.

Wang, L., Chen, A., Fields, K., 2000. Arsenic Removal from Drinking Water by Ion Exchange and Activated Alumina Plants. EPA 600R00088, Prepared by Battelle under contract 68C70008 for U.S. EPA ORD, October 2000.

WHO, 2001. Environmental Health Criteria 224, Arsenic and Arsenic Compounds. WHO, Geneva.

World Bank, 2005a. Arsenic Contamination of Ground Water in South and East Asian Countries, Report No. 31303, vol. I. Policy Report, Environment and Social Unit, South Asia Region, Water and Sanitation-WSP.

World Bank, 2005b. Arsenic Contamination of Ground Water in South and East Asian Countries, Report No. 31303, vol. II. Technical Report, Environment and Social Unit, South Asia Region, Water and Sanitation-WSP.
Xia, Y., Liu, J., 2004. An overview on chronic arsenism via drinking water in PR China. Toxicology 198, 25-29.

Xia, S.J., Don, B.Z., Zhang, Z.L., Xu, B., Gao, N.Y., Causseranda, C., 2007. Study of arsenic removal by nanofiltration and its application in China. Desalination 204, 374-379.

Young, E., 1996. Cleaning Up Arsenic and Old Waste, New Scientist, 14 December, 22 pp.

Zhao, Y., Zouboulis, A.I., Matis, K.A., 1996. Removal of molybdate and arsenate from aqueous solutions by flotation. Separ. Sci. Technol. 31, 769-785.

Zheng, Y., Stute, M., van Geen, A., Gavrieli, I., Dhar, R., Simpson, H.J., Schlosser, P., Ahmed, K.M., 2004. Redox control of arsenic mobilization in Bangladesh groundwater. Appl. Geochem. 19, 201-214.

Zhimang, G., Baolin, D., 2007. Use of iron-containing mesoporous carbon (IMC) for arsenic removal from drinking water. Environ. Eng. Sci. 24, 112-113.

Zouboulis, A.I., Katsoyiannis, I.A., 2002a. Arsenic removal using iron oxide loaded alginate beads. Ind. Eng. Chem. Res. 41, 6149-6155.

Zouboulis, A.I., Katsoyiannis, I.A., 2002b. Removal of arsenates from contaminated water by coagulation-direct filtration. Separ. Sci. Technol 37 (12), 2859-2873.

Zouboulis, A.I., Katsoyiannis, I.A., 2002c. Removal of arsenic from contaminated groundwaters using combined chemical and biological treatment methods. In: Hahn, H., Hoffmann, E., Odegaard, H. (Eds.), Chemical Water and Wastewater Treatment. IWA Publishing, London, pp. 119-130. 